\title{
The Historical Significance of South Africa's Third Force
}

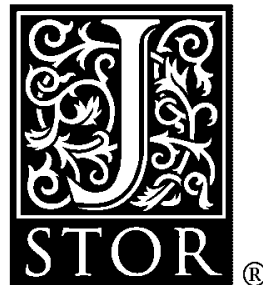

Stephen Ellis

Journal of Southern African Studies, Vol. 24, No. 2. (Jun., 1998), pp. 261-299.

Stable URL:

http://links.jstor.org/sici?sici=0305-7070\%28199806\%2924\%3A2\%3C261\%3ATHSOSA\%3E2.0.CO\%3B2-K

Journal of Southern African Studies is currently published by Taylor \& Francis, Ltd..

Your use of the JSTOR archive indicates your acceptance of JSTOR's Terms and Conditions of Use, available at http://www.jstor.org/about/terms.html. JSTOR's Terms and Conditions of Use provides, in part, that unless you have obtained prior permission, you may not download an entire issue of a journal or multiple copies of articles, and you may use content in the JSTOR archive only for your personal, non-commercial use.

Please contact the publisher regarding any further use of this work. Publisher contact information may be obtained at http://www.jstor.org/journals/taylorfrancis.html.

Each copy of any part of a JSTOR transmission must contain the same copyright notice that appears on the screen or printed page of such transmission.

JSTOR is an independent not-for-profit organization dedicated to creating and preserving a digital archive of scholarly journals. For more information regarding JSTOR, please contact support@jstor.org. 


\title{
The Historical Significance of South Africa's Third Force*
}

\author{
STEPHEN ELLIS
}

(Afrika-Studiecentrum, Leiden)

Accounts of South Africa's transition from apartheid differ markedly in the role they attribute to violence. The most influential narratives of negotiations tend to portray the violence of the transition period, including that perpetrated by those networks within and without the security forces which have become known collectively as the Third Force, as a reaction to events, doomed to failure and rather disconnected from the main narrative of history. Newly available evidence shows the degree to which the Third Force was integrated into the policy of the National Party over a long period, and played a crucial role in determining the nature and outcome of constitutional negotiations in 1990-1994. The consequences of the tactics used by the Third Force, and the legacy of the war for South Africa in general, continue to have an important influence on politics and on society. Analysis of contemporary South Africa can benefit from consideration of the manner in which politics, military activity and crime became enmeshed during a long war.

Most people who lend some attention to South African politics first heard of the Third Force in September 1990 when the phrase was first used in public by leaders of the African National Congress (ANC) including Nelson Mandela, then just seven months out of prison and already established as the organisation's de facto head.

After a brief honeymoon, in which preliminary accords had been signed between the government and the ANC, Mandela had been incensed by a spate of murderous, random attacks on black people, first in the Vaal area and later on the East Rand and on trains running between Soweto and Johannesburg. These attacks, he believed, bore the hallmark of organised, covert government death-squads. There had also been an escalation in the conflict in Natal, notably in the so-called 'Seven-Day War' which ravaged the Natal Midlands in March 1990. Such attacks continued after the ANC had formally announced a suspension of its armed struggle in August 1990. Mandela suggested that a mysterious third party - distinct from the ANC and the National Party, but presumably including members of the security forces - lay behind much of this violence, which President F.W. de Klerk denied.

Although the South African press took to making repeated references to the Third Force after Mandela had first used the phrase in public, and as random attacks such as train massacres and drive-by shootings proliferated, most newspapers were to remain rather vague about the exact nature of the alleged network throughout the period of transition which culminated in the elections of 1994, with the notable exception of the two newspapers which gave most attention to investigating the inner workings of the security

\footnotetext{
* I am grateful to a great number of people who have granted interviews or provided me with documents or helped in other ways with research for this article. I am especially indebted to John Daniel and others at the secretariat of the Truth and Reconcilation Commission, where I worked in July and August 1997 and May 1998, and to Phillip van Niekerk.
} 
services, the English-language Weekly Mail \& Guardian and the Afrikaans-language Vrye Weekblad. Many prominent commentators suggested that, while there certainly were diehards and even organised death-squads in the security forces, the violence in the country was essentially a symptom of rapid political change. Some pointed out that violence was partly, or even largely, the result of the ANC's own previous revolutionary strategy and its earlier call on the people of South Africa to render the country 'ungovernable'. ${ }^{1}$ Others saw the violence as stemming essentially from the government's policy towards the ANC and its allies. ${ }^{2}$

Broadly speaking, the views of both politicians and commentators could be situated on a spectrum, at one end of which were those who believed or claimed that the government was doing its best to administer the country peacefully in a difficult period and that official death squads either did not exist or represented isolated acts of indiscipline. This was the point of view adopted by the National Party itself: Hernus Kriel, then Minister of Law and Order, stated in September 1991 that, 'We are in a period of change in our country, of political change, of constitutional change. And history has taught us that whenever something like that happens in a country, it is always accompanied by some sort of instability'. ${ }^{3}$ According to this view, the violence in the country was largely the result of social upheavals, the culture of lawlessness among youth particularly, and the handiwork of criminals and opposition parties seeking to make gains at a time of contested authority. At the other end of the spectrum of opinion were the ANC and its supporters and allies, who tended to believe that violence was directly or indirectly caused by units of the security forces directed by a government which was pursuing a secret agenda. At times, ANC leaders suggested that the government was perhaps not in full control of its security forces, and that these were intent on sabotaging negotiations completely or even creating the conditions for a military coup.

Since 1994 especially, new evidence has confirmed that a Third Force did indeed exist. Significant new sources of information have included official or judicial inquiries, notably the commission led by Judge Richard Goldstone, established by President De Klerk in 1991 to investigate allegations of security force involvement in political violence, and the proceedings of the Truth and Reconciliation Commission. ${ }^{4}$ Further evidence has come to light through the press and from various other judicial proceedings such as the inquest into the deaths of Matthew Goniwe and others and the trials of Colonel Eugene de Kock and of General Magnus Malan and others. In addition, recently published academic research has shed further light on the Third Force and on the context within which it developed. ${ }^{5}$

It is now clear that the name 'Third Force', in the sense in which it was used by Nelson Mandela in September 1990, is something of a misnomer, since the State Security Council,

1 John Kane-Berman, Political Violence in South Africa (Johannesburg, South African Institute of Race Relations, 1993), pp. 15-27.

2 Morris Szeftel, 'Manoeuvres of War in South Africa', Review of African Political Economy, 51 (1991), pp. 63-76; Martin Murray, The Revolution Deferred: the Painful Birth of Post-Apartheid South Africa (London, Verso, 1994), esp. pp. 73-116.

3 Quoted in Rupert Taylor and Mark Shaw, 'The Dying Days of Apartheid', in Aletta Norval and David Howarth (eds), South Africa in Transition: New Theoretical Perspectives (London, Macmillan, forthcoming).

4 'Interim Report on Criminal Political Violence by Elements within the South African Police, the KwaZulu Police and the Inkatha Freedom Party', by the Commission of Inquiry regarding the Prevention of Public Violence and Intimidation, 18 March 1994. Copy obtained from Human Rights Archive (HURISA), Sandton.

5 See, for example, Gavin Cawthra, Policing South Africa: the South African Police and the Transition from Apartheid (London, Zed Books, 1993); Herbert M. Howe, 'The South African Defence Force and Political Reform', Journal of Modern African Studies, 32, 1 (1994), pp. 29-51; Anthony Minnaar, Ian Liebenberg, Charl Schutte (eds), The Hidden Hand: Covert Operations in South Africa (Pretoria, Human Sciences Research Council, 1994); Annette Seegers, The Military in the Making of Modern South Africa (London, Tauris Academic Studies, 1996); Taylor and Shaw, 'The Dying Days of Apartheid'. 
effectively the most senior organ of government under the presidency of P.W. Botha, began actively discussing the creation of a third force as early as 1985, although in a sense different from that conveyed by Mandela when he first used the phrase in public, as we shall see in due course. But since the expression 'Third Force' has gained both national and international currency, the present article will continue to use the term to designate a substantial, organised group of security officials or former officials intent on perpetrating violence in the service of a counter-revolutionary strategy.

The versions of events during the transition from apartheid to democracy in South Africa which have been most influential throughout the world are probably those published by the journalists Allister Sparks and Patti Waldmeir. ${ }^{6}$ Both these valuable works tend to disconnect the role of violence from the narrative of negotiation. Although Nelson Mandela himself in his best-selling autobiography has indicated that he became gradually convinced of the existence of a Third Force, this occupies only a small section in a generally more edifying account of the transition. ${ }^{7}$ A number of academic studies also regard organised violence as a secondary element, somewhat apart from the main narrative, or at least as a factor out of the immediate control of the negotiators. ${ }^{8}$

It is certainly not our intention to belittle any of these works, or still more, the South African achievement in bringing an end to apartheid without plunging the country into a full-scale civil war. Rather, the purpose of the present article is to demonstrate that concentration on the narrative of negotiations, or indeed any account which fails to give due weight to the perpetrators of organised violence including those who constituted the Third Force, implicitly assigns the violence of 1990-1994 to a position somewhat divorced from, or even antithetical to, the pursuit of negotiation. ${ }^{9}$ This has deflected attention from the important question of ascertaining the extent to which the agenda and pace of negotiations, and thus the shape of the eventual political and constitutional outcome, were actually driven by proponents of violence who were able to make their influence felt from outside the conference chamber. Moreover, many of the people who perpetrated this violence continue to play an important role in South Africa to this day, and in some cases continue to use violence in pursuit of their aims. A reconstruction of the role played by the Third Force raises questions concerning the emerging polity of democratic South Africa which lives with the legacy of this bloody confrontation. Some questions regarding the connection between the political and paramilitary violence of the past and the current epidemic of crime are addressed in the last part of the paper.

The information now available concerning the Third Force compels us to develop a more nuanced view of South Africa's transition. More than 14,000 South Africans lost their lives in violence between 1990 and 1994, more than at any other period of the war to overthrow apartheid. Hence the history of this period may be considered not only as the moment at which moderation and reason triumphed over violence, but also as that in which the war for South Africa, previously fought most ferociously outside the country's borders, now enveloped South Africa itself.

To be sure, there were a number of political organisations and social groups which perpetrated violence in South Africa between 1990 and 1994, including the ANC, which are

6 Allister Sparks, Tomorrow is Another Country: the Inside Story of South Africa's Negotiated Revolution (Struik Book Distributors, Sandton, 1994); Patti Waldmeir, Anatomy of a Miracle: the End of Apartheid and the Birth of the New South Africa (London, Viking, 1997).

7 Nelson Mandela, Long Walk to Freedom (London, Abacus, 1995), pp. 703, 705, 730.

8 See, for example, Timothy Sisk, Democratization in South Africa: the Elusive Social Contract (Princeton, Princeton University Press, 1995); Courtney Jung and Ian Shapiro, 'South Africa's Negotiated Transition: Democracy, Opposition and the New Constitutional Order', Politics and Society, 23, 3 (1995), pp. 269-308.

9 See, for example, Michael MacDonald, 'Power Politics in the New South Africa', Journal of Southern African Studies, 22, 2 (1996), pp. 221-233. 
mentioned in the present essay only in passing. The state-organised or state-connected covert and clandestine networks known as the Third Force were not responsible for all the political violence which occurred in this period, but there is reason to believe that they were by some way its most important sponsors.

\section{War and Politics}

It is appropriate at this juncture to justify our use of the word 'war' to describe the competition for control of the state in South Africa over more than three decades. Those most centrally involved in this contest did not doubt that South Africa was indeed at war between the early 1960s and the early 1990s. For, as Thomas Hobbes observed over three centuries ago, 'Warre, consisteth not in Battell only, or the act of fighting; but in a tract of time, wherein the Will to contend by Battell is sufficiently known ... . So the nature of War, consisteth not in actuall fighting; but in the known disposition thereto'. ${ }^{10}$

Many inquirers, including the Truth and Reconciliation Commission, regard the Sharpeville massacre of March 1960 as the true beginning of hostilities. It was in response to this and other provocations, including the banning of the ANC and the Pan-Africanist Congress (PAC), which then joined the South African Communist Party (SACP) on the list of proscribed organisations, that the ANC and SACP formed an armed wing, Umkhonto we Sizwe. Umkhonto we Sizwe issued a formal declaration of war on 16 December 1961. Thereafter Umkhonto we Sizwe carried out a sabotage campaign for some two years until the arrest of its High Command at Rivonia in 1963. The new leaders of the organisation, now based in exile, came to regard their struggle explicitly as revolutionary in nature, comparable to similar campaigns in Algeria, Vietnam and elsewhere, and they developed a sophisticated strategy of guerrilla warfare. South Africa's National Party government also became convinced that it faced a war of some description. After the mid-1970s, it defined this war as the spearhead of a 'total onslaught', in the words of a 1977 Defence white paper, orchestrated by the Soviet Union, which provided military, diplomatic and other support to the ANC and the SACP and to allied governments in Angola and Mozambique. South African army and police officers who had studied the theory and practice of revolutionary warfare, and who became known as 'securocrats' due to their belief that security structures could be used as institutions for managing political change, devised a counter-insurgency doctrine aimed at mobilising every branch of the state in a campaign to defeat the total onslaught which they believed to be directed from Moscow. A document approved by the State Security Council in 1985 stated that 'there is consensus over the view that the unrest has developed into a revolutionary struggle', although it noted that it would be unwise for the government to use such language in public. ${ }^{11}$ Counsel for the South African Defence Force (SADF) argued before the Supreme Court in 1988 that a de facto state of war existed in South Africa which precluded civil courts from exercising jurisdiction over the state in certain security matters. This argument was, however, rejected by the Court. ${ }^{12}$

The aim of one side in the war was, in the words of the most influential of the military theoreticians on the ggvernment side, 'to subvert and overthrow by force the established regime and to replace it with another'. ${ }^{13}$ The government's counter-strategy, naturally, aimed to prevent such a thing. Murder, torture, smuggling, forgery, propaganda and

10 Thomas Hobbes, Leviathan (Harmondsworth, Pelican, edited by C.B. Macpherson, 1968), pp. 185-186.

11 State Archives, Pretoria: 'Strategie vir die bekamping van die revolusionêre klimaat', appendix to minutes of State Security Council meeting 13/85 (SSC13/85): 26 August 1985.

12 Seegers, The Military in the Making of Modern South Africa, p. 185.

13 Brigadier C.A. Fraser, Lessons Learnt from Past Revolutionary Wars. This text received a restricted circulation in the SADF but was never published. 
subversion were instruments used by both sides in this struggle, but it was the state which brought the greatest resources to bear in these domains. Since Umkhonto we Sizwe could not hope to defeat the SADF on a conventional battlefield, the key to the struggle was to induce the mass of the population to either accept or resist continued government by the National Party. The ANC, increasingly influenced by the SACP's orthodox Marxist analysis, came to consider the black urban proletariat as the most important constituency, and to believe that its own armed struggle could spark a general insurrection or 'people's war'. ${ }^{14}$ Theoreticians on both sides suggested that violence, although important, was not the main element in the struggle, although both sides in practice found it difficult to sublimate the use of armed force to clear political strategies. The thinking of the securocrats on this matter was spelled out by the head of the Security Branch, Lt-Gen. P.J. Coetzee, in a speech in 1982. He pointed out that the battle was not fought just with tanks and guns: $:^{15}$

Perhaps even more important is the battlefield of enemy propaganda and terrorist mythology .... Our target is the collection of individuals and organisations, operating from within and without, who practice or attempt subversion or revolution. The importance of this task at a time of total onslaught against the Republic of South Africa cannot be gainsaid.

'Lt-Gen. Coetzee', added the reporter of the SADF journal which published his speech, 'said that it was on the psychological rather than the physical battlefield where the struggle would be won or lost'.

In the view of the securocrats, then, the aim of violence was less to destroy the enemy's armed forces than to win the support of the population by a mixture of political action, intimidation, propaganda and the symbolic manifestation of authority. In time, the securocrats added to this list the elimination of those socio-economic grievances which made South Africa fertile ground for revolutionaries. For the securocrats, most of whom were professional soldiers and policemen rather than politicians, was essentially a matter of management in which the security and welfare functions of government had to be integrated for the overall purpose of preserving the life of the state. This is the ideology of sophisticated military rulers. They believed that it was above all the use of revolutionary violence and propaganda by the ANC and its allies which accounted for the ANC's success in winning support from what they saw as an essentially manipulable black population, as part of what became, after the late 1970s, a classical revolutionary strategy. The securocrats saw the wave of township violence after 1984 as evidence of this. The ANC intended to implement a revolution, the securocrats believed, by proceeding through four phases beginning with the organisation of an underground apparatus and passing through acts of terrorism to a guerrilla war or people's war. The final phase of such a conflict would be mobile or semi-conventional warfare. Accordingly, the securocrats sought to identify the current phase of the war and to turn it back to the preceding phase, using the revolutionaries' own tactics. For, according to another theorist closely studied by the securocrats, 'the solution to the problem of defeating revolutionary warfare is the application of its strategy and principles in reverse'. ${ }^{16}$

The military and police units which were later to be a central part of the Third Force have their origins in the earliest period of the war in the 1960s. In the following paragraphs, we will briefly trace the history of these units. We will then discuss how they were

14 The ANC strategy, known as The Four Pillars of the Revolution, is perhaps most accessible in articles published in the ANC's official journal Sechaba. The best study is Howard Barrell, 'Conscripts to their Age: African National Congress Operational Strategy, 1976-1986' (University of Oxford, unpublished DPhil, 1991).

15 Quoted in Paratus, 25 September 1982. Article reprinted in Barry Streek, South African Pressclips Supplement. South Africa's Intelligence Services, Part I (Cape Town, mimeo, May 1991).

16 J.J. McCuen, The Art of Counter-Revolutionary War: the Strategy of Counter-Insurgency (London, Faber and Faber, 1966), p. 77. 
organised for counter-revolutionary warfare inside South Africa in the form of the Third Force and the role they played in South Africa's transition from apartheid. The final section of the essay consists of remarks on some of the consequences of the activities of the Third Force.

\section{South African Counter-insurgency}

At the beginning of the armed struggle, in the early 1960s, South Africa possessed two significant security forces: the South African Police (SAP) and the SADF. It was in 1961 that B.J. Vorster became Minister of Justice and Minister of Police. Believing that South Africa was seriously threatened by revolution, ${ }^{17}$ he introduced new security legislation which had the effect of transforming the Police by equipping the force with extensive powers to detain and virtual immunity from prosecution. The change was summarised by Joe Slovo, himself a trained advocate as well as Umkhonto we Sizwe's leading strategist for two decades. 'However firm the old type of policeman ... were [sic], they were not torturers', Slovo later recalled almost nostalgically. 'In a sense up to about 1960-61 the underground struggle was fought on a gentlemanly terrain. There was still a rule of law. You had a fair trial in their courts. Nobody could be kept in isolation. Up to 1963, I know of no incident of any political prisoner being tortured. ${ }^{18}$

All that changed during Vorster's tenure of the Justice and Police portfolios. Vorster promoted his friend H.J. van den Bergh to become, first, head of the Security Branch of the newly-reorganised police, and later, a US-style national security supremo, combining this post with directorship of South Africa's first modern secret service, the Bureau of State Security (BOSS), established by law in 1969 and largely staffed with officers transferred from the Security Branch of the Police. In the process of reorganising a security apparatus built on the Police, Vorster developed for himself a political fief in a key element of the state bureaucracy which was to stand him in good stead when he was elevated to the premiership, still retaining the Police portfolio, in 1966. ${ }^{19}$ He introduced into South African politics a convention whereby any successful political career had to be based on a constituency in at least one element of the security forces. Vorster's own career, his elevation of Van den Bergh, and the primacy of the Police in taking responsibility for the conduct of the war against subversion, were developments so closely associated with one another that Vorster's eventual decline was also reflected in that of the institutions which were so marked by his hand, to the point that BOSS itself was abolished and Van den Bergh forced into retirement when Vorster resigned in $1978 .{ }^{20}$ The Police service was to be eclipsed as the paramount security service as a result of Vorster's replacement as premier by Defence Minister P.W. Botha, whose power-base lay partly in the military, whose minister he had been since 1966.

Over the years, the SAP, and most particularly the Security Branch, developed a characteristic view of subversion. To some extent the origins of this lay in the SAP's own evolution from a colonial-style mobile police force. ${ }^{21}$ Long before the outbreak of hostilities in the 1960s, and indeed even before the National Party government came to power in 1948, the SAP had developed a strategy for policing African populations, in conformity with the

17 Seegers, The Military in the Making of Modern South Africa, p. 125.

18 Joe Slovo, 'The Sabotage Campaign', Dawn, special anniversary issue [1986], p. 25.

19 Seegers, The Military in the Making of Modern South Africa, pp. 125-126.

20 Eschel Rhoodie, P.W. Botha: the Last Betrayal (Melville, SA Politics, 1989), is an essential, though partisan, source. For a more staid account, see Brian Pottinger, The Imperial Presidency: P.W. Botha, the First Ten Years (Johannesburg, Southern Book Publishers, 1988).

21 The official history of the SAP is Marius de W. Dippenaar, The History of the South African Police, 1913-1988 (Silverton, Promedia, 1988). This may be read in conjunction with unofficial studies, such as Cawthra, Policing South Africa. 
British colonial tradition of indirect rule. The latter was a system of government which aimed to keep Africans as far as possible in rural areas under their own traditional or quasi-traditional rulers. In English-speaking southern Africa, it included provision for rural African men especially to move to the towns as migrant workers who could live in cities and mine compounds for a specified period before returning to their home areas and their families after their contracts had expired. Indirect rule required government officials to identify and promote local rulers, hereditary chiefs if possible, who would govern rural areas as far as practicable by their own devices and according to customary law. The role of the national police force, then, was to ensure that chiefs did not contravene the laws of the central government which applied in those rural areas designated as African reserves, or the later apartheid creations of bantustans or homelands, and to act as a mobile armed force when intervention was necessary. Any significant agitation against a chief regarded by the government as legitimate was interpreted by the Police as a form of insurgency.

The Police continued to apply this policy in the vastly different environment of the urban areas which emerged with South Africa's industrialisation, despite the fact that most black townships were ethnic melting pots with no rulers who could be regarded as traditional. The growth in the African population of the cities left the Police attempting to carry out its traditional task of seeking local strongmen with an ethnic constituency, in the absence of any clear government policy on cultivating political institutions in black urban areas. Not until the 1980s did the government try to develop a coherent policy on the representation of Africans in urban areas, and by that time, control of the townships was being contested by armed revolutionary organisations such as the ANC and the PAC. The Police found it difficult to identify people of influence who would work with them but who could also command respect among the black population, and resorted to cultivating informer networks and repressing anti-apartheid activity with the immense powers at their disposal. At no stage were policemen operating in black urban areas able to dispose fully of the most important element of all successful policing, namely the active support of the local population.

To this tradition was added a corpus of experience gained directly in border wars in Rhodesia and Namibia. In 1967, Umkhonto we Sizwe, now based in Tanzania, developed a new strategy known as 'hacking the way home'. This envisaged a campaign of rural guerrilla warfare in Rhodesia, intended to open up a Ho Chi Minh trail to South Africa. Implementation of this plan depended on an alliance with ZIPRA, the armed wing of the Zimbabwe African People's Union (ZAPU), at that time the premier Zimbabwean nationalist movement. After a joint Umkhonto we Sizwe/ZIPRA force had infiltrated Rhodesia in August 1967, SAP units were sent to work alongside the Rhodesian security forces. By 1975, as many as 2,000 South African policemen were stationed in Rhodesia. A further theatre of rural conflict emerged in the north of Namibia, the South African colony threatened by the guerrilla army of the South West African People's Organisation (SWAPO), based first in Zambia and, after 1975, in newly-independent Angola. In Namibia too it was initially the Police and not the SADF which was deployed.

The key lesson learned by South African policemen on detachment in Rhodesia was the value of intelligence in irregular warfare of this sort. The best and most useful intelligence was that obtained from an active guerrilla who, after capture, could be induced to give information on his unit before it had had time even to register his absence. Once such intelligence had been obtained, it would rapidly become obsolete if passed from an intelligence-gathering unit via the central chain of command to an offensive unit, giving the enemy time to move position. Some Rhodesian commanders advocated the creation of intelligence-gathering units which also had an offensive capacity. The main Rhodesian unit of this type was the Selous Scouts, which specialised in 'pseudo-operations', a technique 
learned from British forces in Malaya and Kenya and the Portuguese flechas or irregular police troops in Mozambique and Angola. The Selous Scouts, using black troopers disguised as nationalist guerrillas, operated in enemy territory, capturing and interrogating guerrillas and using the intelligence gathered to launch an immediate surprise attack. After such an act of treachery, a captive could not return to his guerrilla organisation but could now be induced himself to become a Selous Scout, by which time he had been definitively 'turned'. ${ }^{22}$ Such 'turned' guerrillas were called askaris, a Swahili word acquired by British forces in the Mau Mau insurgency and transmitted via Rhodesian officers to the South African Police. The Selous Scouts killed more people than the rest of the Rhodesian armed forces put together. ${ }^{23}$ They rapidly became a law unto themselves, and Rhodesia's intelligence chief later judged the militarisation of pseudo-operations to be 'the worst mistake I made in the conduct of the war'. ${ }^{24}$

There can be no doubt of the importance of the Rhodesian experience in forming the views of South African counter-insurgency specialists who were later to become key members of the Third Force. Among the South Africans who served in Rhodesia, for example, was Eugene de Kock, who joined the South African Police in 1968 and, as a young constable, served 10 or 11 tours of duty in Rhodesia between then and 1972. He trained with various Rhodesian military units including the Special Air Service (SAS) and the Rhodesian African Rifles. It is notable that, whereas a policeman is in theory employed to uphold the law of the land with the minimum use of force, De Kock was partly trained by a military unit specialised in long-range reconnaissance, sabotage and fighting behind enemy lines. The Rhodesian SAS, originally a squadron of the British SAS, had served in the Malayan insurgency where leading Rhodesian officers such as General Peter Walls, later to become the commander of the Rhodesian army, and Lieutenant-Colonel Ron Reid Daly, commander of the Selous Scouts, had learned the dark arts of counter-insurgency. ${ }^{25}$ The lessons he learned in Rhodesia, says De Kock, 'made sense to me. Why keep to the Queensberry rules and fight one boxer when you can kick them in the balls and kill three?'26

Like De Kock, many of the policemen who were to emerge at the heart of the underground war against subversion in South Africa served in Rhodesia. They included General Hans Dreyer, the founder of the Koevoet unit. Koevoet, established by Dreyer on behalf of the Security Branch in Namibia in 1979 with officers who had served in Rhodesia, was another formative influence. Dreyer, having begun with the idea of using Koevoet in imitation of the Selous Scouts, soon decided that the intelligence function was secondary, and that 'highly mobile and heavily armed hunter-killer teams were the best way of dealing with insurgents in the thick bush of Ovamboland' ${ }^{27}$ De Kock, a founder-member of Koevoet, recalls that during four years in the unit he was involved in some 350 contacts with the enemy. He left Koevoet in 1983 suffering, he now believes, from post-traumatic stress, a condition which went unrecognised by his superiors. 'There was no such thing as counselling', he recalls, 'they wanted kill-rates'. ${ }^{28}$ Particularly alarming, from the point of

22 Ron Reid Daly, as told to Peter Stiff, Selous Scouts: Top Secret War (Alberton, Galago paperback edition, 1983), esp. pp. 175-181.

23 Ibid., p. 15.

24 Ken Flower, Serving Secretly: Rhodesia into Zimbabwe, 1964-1981 (London, John Murray, 1987), p. 124.

25 Reid Daly, Selous Scouts, pp. 76, 478.

26 Colonel Eugene de Kock, interview with Phillip van Niekerk, Pretoria Central Prison, 3 March 1996. A brilliant film biography of De Kock is by Jacques Pauw. Entitled 'Prime Evil', it was first broadcast on South African Television on 21 October 1996.

27 Jim Hooper, Beneath the Visiting Moon: Images of Combat in Southern Africa (Lexington MA, Lexington Books, 1990), p. 110. A hostile view of Koevoet is Denis Herbstein and John Evenson, The Devils are Among Us: the War for Namibia (London, Zed Books, 1989), pp. 61-95.

28 Interview with Colonel Eugene de Kock by Phillip van Niekerk, Pretoria Central Prison, 3 March 1996. There is also abundant information in the records of De Kock's 1996 trial by the Pretoria Supreme Court. 
view of traditional policing, was the practice developed by Koevoet, based on the Rhodesian experience of so many of its officers, of using 'turned' guerrillas as troopers in the security forces without giving them a formal indemnity for their earlier offences. In the long run this could only bring the central principle of the law into disrepute.

Battle-hardened, psychologically and socially divorced from their communities of origin and compromised by their treachery, askaris were well-suited to the grisliest acts of war. After De Kock had returned to South Africa in 1983 he was drafted into the C 1 unit of the Police based at Vlakplaas where he became commander in 1985. This unit (later renamed C 10), founded in 1979 by yet another veteran of the Rhodesian war, was largely composed of askaris, former fighters from Umkhonto we Sizwe, the PAC, ZIPRA and several other guerrilla armies of southern Africa. After the independence of Namibia in 1990, its ranks were swelled by former Koevoet troopers, some of them originally members of SWAPO, bringing the number of askaris under De Kock's command to over 300. From 1979, but especially under De Kock's command, the C 10 unit became a general-purpose death-squad which would be handed instructions to kill specific individuals who had been identified by the Security Branch in various parts of the country as well as acting on the initiative of its commander, who had an effective power of life and death. Like their mentors in the Selous Scouts, the Vlakplaas askari commanders developed a sense of immunity and eventually performed all manner of freelance operations, including armstrading and diamond-trafficking, which their superiors would routinely overlook or cover up. ${ }^{29}$ After 1986, various provincial police commands also developed their own askari units, such as that run by Colonel Andy Taylor in Natal.

The techniques of counter-insurgency developed by the SAP in Rhodesia and Namibia thus made their appearance in South Africa itself. Colonel Theunis 'Rooi Rus' Swanepoel, the architect of the bloody repression of the Soweto rising of 1976, for example, had taken part in the first counter-insurgency operations against SWAPO in northern Namibia ten years earlier. ${ }^{30}$ Swanepoel was one of a dozen policemen who had trained on detachment in Algeria in the last days of French rule. The Police were increasingly ruthless in the use of torture and various techniques learned from other countries including Israel, Chile and Argentina, the latter at the height of 'dirty wars' of their own. ${ }^{31}$ In combination with the sweeping legal powers introduced in the early 1960s, these factors created a culture of brutality within the Police. ${ }^{32}$

Many of the Security Police techniques of intelligence-gathering were learned by sections of the military, despite the sometimes bitter rivalry between the two services. Until the 1970s the SADF had been a fully conventional force. The favour which John Vorster showed to the SAP and BOSS prevented the SADF from taking a prominent role in counter-insurgency. Nevertheless a few officers had given some thought to the security problems facing South Africa. The young Magnus Malan imbibed the latest US theories of counter-insurgency on courses in the USA in 1962-1963. Even as a junior officer he was regarded as a rising star in the military due to his father's political connections with P.W. Botha, Minister of Defence after 1966, and due to Malan senior's standing in the Broederbond, the Afrikaner secret society which has played such an important role in National Party politics. ${ }^{33}$ Malan took command of the Namibian border in 1966 and later,

29 Author's interviews with former members of C10 unit, Pretoria, May 1996. Also see Pauw, 'Prime Evil'. In 1996, the Pretoria Supreme Court convicted De Kock of 89 offences, including six murders.

30 Cawthra, Policing South Africa, p. 19.

31 Ibid., pp. 19, 27.

32 Patrick Laurence, Death Squads: Apartheid's Secret Weapon (London, Penguin Forum Series, 1990), pp. 63-69.

33 Works on the Broederbond include Ivor Wilkins and Hans Strydom, The Super-Afrikaners: Inside the Afrikaner Broederbond (Jonathan Ball, Johannesburg, 1978), and J.H.P. Serfontein, Brotherhood of Power: an Exposé of the Secret Afrikaner Broederbond (London, Rex Collings, 1979). 
as head of the Army, established systems of joint counter-insurgency committees in the territory which were to serve as models for South Africa itself. A former Army chief, Lieutenant-General Alan 'Pop' Fraser, wrote two privately-circulated studies of counterinsurgency based on British, American and French experience of low-intensity wars. Fraser, a veteran of the Malaya campaign, was instrumental in disseminating the view which was to prevail among a later generation of securocrats that the basic site of revolutionary warfare is none other than the population itself, and that counter-revolutionary warfare must operate on the same terrain. ${ }^{34}$

In 1975, responding to the imminent independence of Angola, the SADF launched its first major operation since the Second World War, penetrating deep into Angola in an effort to prevent a Soviet-allied government from coming to power in Luanda. Although the South African forces were to get close to Luanda, their intervention was a disaster. The operation failed to achieve its objective of installing a pro-Western government, but instead provoked the intervention of a Cuban expeditionary force, thus internationalising the Angolan conflict and compounding the very problem which the SADF had set out to solve. The catastrophic SADF intervention in Angola in 1975-1976, stymied by poor intelligence and confused political decision-making, taught the SADF the necessity of coordinating different branches of activity if its military efforts were to be successful. In 1977, the SADF unveiled a doctrine called a 'total strategy' which proposed sublimating every aspect of national life to the defence of the state against subversion. As far as South Africa's immediate neighbours were concerned, this meant using every available means to prevent or dissuade them from supplying the ANC and its Namibian counterpart, SWAPO, with bases.

Henceforth, the SADF preferred to stop short of invading neighbouring countries, other than Angola, where it was too deeply committed to pull out entirely. Instead, the securocrats, who acquired such great power in South Africa after P.W. Botha's elevation to the premiership in 1978 , developed a variety of instruments to influence South Africa's neighbours, including the offering of diplomatic and economic inducements and a technique of destabilisation involving the use of economic sanctions, sabotage, sponsorship of anti-government groups, propaganda and other techniques in order to create chaos in the country targetted, with a view to making its government more pliable to Pretoria's will. For these purposes the Department of Foreign Affairs was drawn into the securocrats' ambit. $^{35}$

These aspects of the total strategy were regarded as state secrets and were not revealed to the South African public. Officially, sabotage operations in neighbouring countries, the use of death-squads to assassinate opponents of the government at home and abroad, and the use of torture, did not exist in South Africa. Generally speaking, the more gruesome tasks associated with the total strategy were entrusted to specialist units of the SAP or the SADF. In the SADF, Military Intelligence, the Special Forces (founded in 1974) and auxiliary units such as 32 Battalion were the leading specialists in this type of activity. Within the Police, the Security Branch, and especially C 10, based at Vlakplaas, became specialists in covert or clandestine warfare. Here lay the origins of the Third Force, among professional counter-insurgency specialists with long experience of border wars which, as the years went by, they increasingly applied in South Africa itself.

34 C.A. Fraser, 'Revolutionary Warfare: Basic Principles of Counter-Insurgency', no place or date. Extracts from this work were translated into Afrikaans with a foreword by P.W. Botha and circulated to senior officials in 1986. See note 57, below. Extracts from the work of J.J. McCuen were similarly circulated among senior officials in abridged form.

35 Joseph Hanlon, Beggar Your Neighbours: Apartheid Power in Southern Africa (London, CIIR and James Currey, 1986). 


\section{Counter-revolutionary War Abroad and at Home}

The change of government in South Africa in 1978 cleared the way for military commanders to implement the total strategy outlined in the 1977 Defence white paper. Prime Minister Botha, who retained the Defence portfolio until 1980 when it passed to his protégé General Malan, presided over a thorough overhaul of both the strategy and the machinery of government which gave immense power to the securocrats.

The whole point of the total strategy was that it was not limited to purely military matters. It also concerned, for example, control of information and of strategic industries such as arms production and power generation. In response to, or anticipation of, the imposition of economic sanctions, the securocrats concerned themselves with the encouragement of alternative networks for trade not only in strategic commodities such as oil, but even in the normal products of South African agriculture and industry. Even welfare ministries had a role to play.

All of these matters were coordinated by a National Security Management System which was developed after 1979. (Later, this became known simply as the National Management System after welfare ministries had been integrated into it.) This apparatus was overseen by the State Security Council, a sub-committee of the Cabinet which, after it had acquired its own full-time secretariat in 1979, became more powerful than the Cabinet itself. ${ }^{36}$ Thanks to these arrangements the securocrats, led by P.W. Botha, made considerable progress in coordinating the different departments of state and in gaining command of a state bureaucracy which had expanded enormously in the previous two decades. Senior securocrats believed that Vorster's ad hoc style of government had allowed the machinery of government to run out of control. Their own military culture caused them to impose a more rigorous centralisation than had previously existed and Botha, a talented administrator as well as a powerful politician, found this to his taste. The State Security Council in effect functioned as the apex of a complex system of committees designed to coordinate the work of security and welfare departments, and even, at times, of civic and business organisations, at every level of government. Every part of the country was overseen by a local Joint Management Committee, dominated by security personnel, which coordinated the action of government agencies within its area, and even brought some non-officials within its scope. ${ }^{37}$ If a township was considered to be under the influence of government opponents, the local Joint Management Committee could identify the ringleaders for arrest or even murder while simultaneously arranging for the improvement of local social services in an effort to stem the conditions which gave rise to political discontent. Hence, a massacre at the small Natal settlement of Trust Feed in 1988, for example, was planned by the local Joint Management Committee, and actually carried out by the secretary of the Committee, Police Captain Brian Mitchell. ${ }^{38}$

By 1979, Botha had installed the basis of this formidable machinery. Responding to intelligence that senior ANC and SACP officials had been on a study-tour to Vietnam, and were developing a new strategy based on the insights of the legendary General Vo Nguyen Giap which would abandon the concept of semi-conventional rural guerrilla warfare in favour of an urban strategy, ${ }^{39}$ leading securocrats held a conference at Fort Klapperkop in 1979. Also present was an Argentinian visitor, one General D'Almeida. The conference resolved to develop the SADF's Special Forces wing, shortly to come under the control of

36 Seegers, The Military in the Making of Modern South Africa, pp. 161-165.

37 Johan C.K. van der Merwe, 'Die Staatsveiligheidsraad: die Ontwikkeling van 'n Stelsel vir Veiligheidsbestuur in die Republiek van Suid-Afrika, 1972-1989' (unpublished PhD thesis, University of South Africa, 1990).

38 Deneys Coombe, 'The Trust Feed Killings', in Minnaar et al. (eds), The Hidden Hand, pp. 191-211.

39 Howard Barrell, 'The Turn to the Masses: the African National Congress's Strategic Review of 1978-79', Journal of Southern African Studies, 18, 1 (1992), pp. 46-92. 
General 'Kat' Liebenberg, so as to disrupt the ANC's development of military bases in neighbouring countries. ${ }^{40}$ After 1979 , the aggressive strategy adopted by the South African government towards its neighbours was reinforced by the presence in the USA and Great Britain of strongly anti-communist governments.

The most thoughtful securocrats were aware that the system of apartheid was at the heart of South Africa's political problems and proposed as a solution a programme of political reform. The centrepiece of this was the new constitution unveiled in 1983, which provided for limited power-sharing with Indian and Coloured South Africans. To this was later added a programme of socio-economic upliftment. The securocrats' hope was that in the fullness of time the integrated policies of repression and improvement would create space for the development of new political forces which would provide the black population with a gradualist view of change in contrast to the revolutionary programme of the ANC, SACP and PAC. By early 1984, the government believed that its strategy was working. The new constitution, although widely spurned even by the Indian and Coloured voters it was intended to woo, was in place and the government had negotiated a treaty with Mozambique, the Nkomati Accord, which would help drive Umkhonto we Sizwe out of strikingdistance from South Africa. President Botha, in unmistakably triumphalist mode, observed to members of the State Security Council that the total strategy was one 'which is perhaps not perfect, but which works'. ${ }^{41}$

Within a year, this view was to change radically. In September 1984, a wave of rent boycotts and other protests broke out in the Vaal Triangle and spread rapidly, leading to violent disturbances which were met with brutal counter-methods by the Police. So intense was the conflict in Sebokeng that the SADF was deployed in the township, which did much to sharpen the always latent antagonism between rival security forces. With the United Democratic Front (UDF), the pro-ANC front founded in 1983, having great success in providing a national focus to various local conflicts, the ANC believed that a popular rising was at hand and called on South Africans to make the country 'ungovernable'. The dreaded petrol-filled tyre or 'necklace' made its appearance and became widely regarded as the ultimate weapon of pro-ANC 'comrades'. According to the SADF, between 1984 and 1989, 399 people died as a result of necklacing. ${ }^{42}$

The government was now facing a virtual insurrection more serious even than that 1976, since this time around the insurgents were better organised, were supported by an armed guerrilla movement and had the support, or at least the sympathy, of substantial parts of South African society and of world public opinion. Government ministers saw the hand of the ANC - and behind it, of the Communist Party - everywhere. Even before the Vaal Triangle uprising, exasperated ministers had expressed their concern 'over the use made by the enemy of the trade unions, the courts, the press, political parties, Parliament and other democratic institutions, with a view to undermining the Republic of South Africa' ${ }^{43}$

Determined to restore control of the country and to regain the political initiative, the government took a series of radical measures which changed the nature of the struggle and which, importantly for the subject under discussion, gave shape to what was later to be called the Third Force.

In January 1985, the State Security Council approved a major new system of propaganda projects known as Strategic Communication or Stratcom. ${ }^{44}$ Although these projects

40 Confidential interview, 11 June 1997.

41 Minutes of SSC 4/84: 5 March 1984.

42 'SA Defence Force Involvement in the Internal Security Situation in the Republic of South Africa', p. 24, unpublished document by South African National Defence Force, 1997.

43 Minutes of SSC 2/83: 7 February 1983.

44 Minutes of SSC 1/85: 21 January 1985. 
were in theory concerned with the dissemination of information and disinformation, many involved blackmail, libel and manipulation of such a mischievous type that, in situations of acute unrest, they could lead to murder and other bloodshed, as we shall see. Throughout 1985 , as the situation slipped from bad to worse, almost every fortnightly meeting of the State Security Council brought new measures designed to restore the government's control. On 18 March 1985, the Council broadly approved a document presented to it by its secretariat on the revolutionary climate in South Africa. Approving a plan to arrest key leaders of the agitation on a selective basis, President Botha said he was concerned that the impression was being given 'that the state's authority is being undermined and that action is not being taken in a sufficiently focussed way' ${ }^{45}$ Reflecting on the matter at the next meeting, Botha announced that he wanted to meet privately with 20 to 22 senior officers of the security forces to talk to them 'about how to fight the revolutionary climate'. He added that the government would meanwhile continue with its reforms, but that there was no question of conceding one person, one vote. ${ }^{46}$ When exactly this meeting took place is not known, but one police general who attended said that 'PW gave us hell', and that 'he told us we must take the gloves off' ${ }^{47}$

By July 1985, the situation had not improved. Deputy Minister of Law and Order Adriaan Vlok told the State Security Council that 'the security forces are doing everything they can but that the unrest situation is continuing and that law and order cannot be restored in affected areas, and that damage and loss of life are on-going' ${ }^{48}$ The same meeting decided to impose a partial State of Emergency two days later. ${ }^{49}$ The following month, August 1985, while the world focussed on Botha's botched Rubicon speech, and Chase Manhattan became the first major bank to announce it was leaving South Africa, President Botha became yet more obdurate. He said that the country could not wait for legal proceedings against the UDF to take their course, and that 'order must be restored'. The State Security Council approved an intelligence assessment which noted that South Africa was now fighting a revolutionary war, although this assessment should not be publicised for fear of alarming the population. ${ }^{50}$ This amounted to a formal finding that the revolutionary onslaught had now reached the phase of guerrilla war inside South Africa and the securocrats believed, following the tenets of their strategic guides Fraser, McCuen and others, that the appropriate step was to fight fire with fire, organising guerrilla forces of their own for deployment inside South Africa.

It was in these circumstances that the government first began to debate the establishment of a third force. To this end, the secretariat of the State Security Council began assembling academic articles and other material on special anti-insurgency or anti-terrorist forces in Europe and elsewhere. ${ }^{51}$ When the State Security Council first considered the subject, in November 1985, it was clear that it was thinking in terms of setting up a special paramilitary unit, more aggressive than the Police but, unlike the Army, devoted to internal security. Over the following months, SADF and SAP representatives differed, with the Police arguing for the creation of a strengthened riot police, and the SADF maintaining that a 'third force' capacity already existed within its ranks, in the Army's counter-insurgency forces such as the Special Forces and the Special Tasks directorate of the Chief of Staff

45 Minutes of State Security Council (hereafter SSC) 5/85: 18 March 1985.

46 Minutes of SSC 6/85: 15 April 1985.

47 Confidential source.

48 Minutes of Extraordinary meeting of SSC, 18 July 1985.

49 Ibid.

50 Minutes of SSC 13/85: 26 August 1985.

51 The first such article in the file is Charles Nelson (of Thames Valley Police), 'Third Force: an International Police Association Scholarship Report', Police Journal, 53 (April 1980), pp. 138-146. SSC File 22/1/1/3/3, vol. I. 
(Intelligence). ${ }^{52}$ The former unit had been responsible for many cross-border raids, while the latter was the organisation which ran South African support to the União para a Independência Total de Angola (UNITA) in Angola, and the Resistência Nacional Moçambicana (RENAMO) in Mozambique, as well as overseeing the destabilisation of Zimbabwe and Lesotho. It is significant that one of the main police representatives in staff meetings on the third force was Brigadier J.J. Viktor, the original architect of the Vlakplaas death-squad. President Botha himself was adamant that such a third force must be prepared to be unpopular and even 'feared'. He added that the security forces had to cooperate on the new force 'so that the subversives can be fought using their own methods'.53

The Police and the SADF were never able to agree on the constitution of a third force since both argued either that such an agency should be under their control, or that they already had the means to carry out the functions allotted to such an organisation. But both Police and Army were in time to create units, or adapt existing ones, to carry out the job of undertaking internal repression of the robust nature which the government required, noting the State President's repeated injunctions to the security forces to cooperate with each other. Deputy Minister Vlok was detached from his usual functions to chair a Joint Security System housed within the secretariat of the State Security Council. Some time in 1985 or 1986, a high-level intelligence committee known from its Afrikaans acronym as Trewits was established to coordinate intelligence and to designate targets for action: in effect, to sentence them to death. ${ }^{54}$ As the highest level of government expressed the conviction that the country was now facing a revolutionary war within its own borders, and as the President bullied and exhorted his security forces to restore order at all costs, the departments of state responded by putting in place the mechanisms of an organised network of illegal repression. In July 1985, Eugene de Kock, one of the most feared and admired veterans of Koevoet, was put in charge of the $\mathrm{C} 1$ death squad at Vlakplaas, and thereafter some provincial police commands established their own askari units to carry out murders. In May 1986, the Civil Cooperation Bureau was established as a front company by Special Forces on the orders of senior military personnel and the Minister of Defence, and the following month, the head of Special Forces was ordered to deploy his forces, using 'unconventional methods', in support of the Police. ${ }^{55}$ After the institution of a nationwide State of Emergency in June 1986, the CCB undertook its own operations abroad and carried out assassinations in support of the Police at home, before establishing a comprehensive internal organisation in 1988. The SADF Chief of Staff (Intelligence) set up a clandestine operation to train 200 paramilitary personnel for Inkatha, while a similar attempt was also made to create a pro-government paramilitary force in the Transkei and Ciskei. In effect, military units, which had carried out the destabilisation of neighbouring countries, were now implementing similar strategies at home, on the instructions of the State President, the State Security Council and the head of the SADF.

In April 1986, the State Security Council had endorsed guidelines for a strategy for counter-revolutionary war which, among other things, emphasised that the forces of revolution should not be combatted by the security forces alone, but also by 'anti-revolutionary groups such as Inkatha ... or the ZCC [Zion Christian Church] as well as the ethnic factor in South African society'. In the following months, specifically ethnic

52 File 22/1/1/3/3, vol. 1, especially the report on behalf of the SADF by Brigadier B.A. Ferreira, 28 February 1986.

53 Minutes of SSC 7/86: 12 May 1986.

54 Author's interview with Colonel Eugene de Kock, Pretoria Central Prison, 4 May 1996.

55 Amnesty application by Major-Gen A.J.M. Joubert, May 1997. 
organisations were armed and trained in KwaZulu and Ciskei, while anti-ANC groups in other places were encouraged and armed in the form of kitskonstabels or special policemen and vigilantes. This was perhaps the most effective counter-revolutionary tactic of all since vigilantes could fight the comrades of the ANC in their own communities. Most obviously, this took the form of arming potential allies among the black population to fight the pro-ANC 'comrades' who had taken control of some townships. ${ }^{56}$ At the same time, this pushed KwaZulu Natal beyond the brink of civil war and brought other areas close.

In September 1986, President Botha ordered General Fraser's handbook on counterrevolutionary war to be translated into Afrikaans and circulated to senior officials with a foreword by the State President in which he expressed the wish for them to assimilate and apply these principles ${ }^{57}$ which were based on the concept that the style of revolutionary guerrilla warfare which was being used against the South African state could be countered only by using the same techniques in reverse. In paragraph 33 of his original work, Fraser noted on terrorism: 'As the goal of modern warfare is the control of the populace, terrorism is a particularly appropriate weapon since it aims directly at the inhabitant'. He went on to caution that it should be used by the counter-revolutionary power only with the greatest circumspection, and only with approval 'at the highest level' ${ }^{58}$ In other words, terrorism, as used by the enemy, could also be used by the state's security forces, provided only that this was done 'with the greatest circumspection' and under appropriate political control.

\section{The Ambiguity of Command}

It is in the nature of hierarchies for the precise conditions on the ground to differ on occasion from the intentions of those making strategic decisions at the top of the organisation. Moreover, the senior officials who ran the National Management System at its upper reaches were familiar with the usual techniques of civil servants, including the use of circumlocutions designed to save their political masters from embarrassment and the studied cultivation of ambiguity which permits a functionary to secure a favourable response to lines of action which he (never she, since no women are known to have held posts at the higher levels of the National Management System) hopes will be approved; this is what a senior British official once famously called 'being economical with the truth'. Nevertheless, instances in which the flow of documents from the bottom of the security hierarchy to the apex of the system have come to light illustrate that the State Security Council was well informed of events within its sphere of responsibility. In the case of a leading UDF and underground ANC activist in the Eastern Cape, Matthew Goniwe, a provincial military commander who also chaired the Eastern Province Joint Management Committee ordered the secretary of this JMC to signal the head of the Strategy Branch of the Secretariat of the State Security Council requesting permission to effect the 'permanent removal from society' of Goniwe and others. The request is known to have been discussed at senior levels of the National Management System. On 27 June, Goniwe and three

56 Nicholas Haysom, Mabangalala: the Rise of Right-wing Vigilantes in South Africa (Occasional Paper No. 10 , Centre for Applied Legal Studies, University of the Witwatersrand, Johannesburg, 1986). A book-length official report on the organisation of vigilantes is Major-General F.M.A. Steenkamp, 'Alternatiewe Strukture as Faktor in die Rewolusionêre Aanslag teen die RSA' (Pretoria, unpublished, South African Police HQ, February 1987).

57 C.A. Fraser, Revolusionêre Oorlogvoering: Grondbeginsels van Teeninsurgensie (restricted circulation, 10 September 1986). This is an Afrikaans translation of extracts from Fraser's work referred to at note 34 above.

58 Fraser, Lessons Learnt From Past Revolutionary Wars, para. 33. 
colleagues from the leadership of the United Democratic Front in Cradock were murdered. ${ }^{59}$ A judge was to find that there was prima facie evidence that both the Chairperson and the Secretary of the Eastern Province JMC had intended the order to mean that Goniwe and others should be killed. It is now known that the murders were carried out by local members of the Security Police. In another case, when the State Security Council in 1986 gave approval for the SADF to train some 200 military personnel on behalf of Inkatha, the papers submitted to the State Security Council did not mention that these were to be used in an offensive capacity. ${ }^{60}$ The provision of an offensive capability was discussed only at a slightly lower level of the bureaucracy. Nevertheless, it must have been apparent to members of the Council that, given the nature of the conflict between Inkatha and the ANC in the province, the provision of trained military personnel to Inkatha could only fan the flames of war in the area. In these and similar cases it is apparent that the securocrats who ran the National Management System had become adept in using exactly the combination of euphemism and ambiguity which was necessary to centralise decision-making while avoiding language which would allow a court of law to convict senior officials and ministers of responsibility for law breaking. Senior Police officers who asked their political masters what exactly was meant by phrases such as 'eliminate', 'wipe out' or 'remove from society' were often told that they knew what had to be done, and that they should take appropriate precautions. ${ }^{61}$

Here, then, was a paradox, for while the state as a whole was being rigorously centralised, there was an increasing tendency for covert units to act on the Special Forces' principle of 'need to know' in order to promote operational effectiveness while minimising the risk that senior officials would be embarrassed. ${ }^{62}$ An important consequence of this was that covert operatives acquired greater scope to raise money from their operations. For example, covert military operatives ran ivory, hardwood, diamonds and other products out of Angola through a front company on a large scale from the late 1970s. The operation was personally approved by General Malan while he was still head of the SADF before $1980,{ }^{63}$ and yet neither the financial administration of the SADF nor the State Security Council appears to have been informed. ${ }^{64}$ The need-to-know principle generally used in covert operations precluded knowledge of the trade from circulating through normal managerial channels. What happened to the income generated by the Angolan trade remains unknown, but the implication is clear: covert operations not only increased enormously the possibilities of corruption, but covert units had a tendency to fracture into vertically-integrated patronage systems whereby covert operators in the field could carry out illegal operations on the authority of just one senior central official, by-passing various committees designed to coordinate government action. Just as happened with the Selous Scouts in Rhodesia, so in South Africa certain covert units were kept under close control only for as long as their patron had the political will and the necessary means. If the patron found it expedient to distance himself from an operation for political reasons, covert units which had grown accustomed to handling largely unaccountable funds were able to operate with progressively less oversight. Moreover, the contacts which military men made with local government agencies and business people through the network of Joint Management Committees and

59 Sam Sole, 'The Hammer Unit and the Goniwe Murders', in Minnaar, Liebenberg and Schutte (eds), The Hidden Hand, pp. 277-286.

60 The documents in question were produced in evidence at the 1996 trial of Magnus Malan and others in Durban.

61 Confidential interview, 11 June 1997.

62 Seegers, The Military in the Making of Modern South Africa, p. 311.

63 Justice M.E. Kumleben, Commission of Inquiry into the Alleged Smuggling of and Illegal Trade in Ivory and Rhinoceros Horn in South Africa (Pretoria, State Printer, 1996).

64 Author's telephone interview with Major-Gen. A.J. van Deventer, Pretoria, 10 May 1996. 
similar parallel administrations gave them exceptional possibilities to intervene in almost any sphere of life.

One of the main concerns of the National Management System was to minimise the always latent, and sometimes intense, rivalry between competing security services. To this end, the secretariat of the State Security Council was able at an early stage to arrange an effective division of functions between the SAP's intelligence-gathering apparatus, Military intelligence and the National Intelligence Service, the latter being the former BOSS, now shorn of its offensive capability. This was decided at an important conference held at Simonstown in January 1981. The Police's main role was internal, but it continued to have some external assets. The arrangement made at the Simonstown conference was that, in principle, the SAP would run agents and also offensive operations in Swaziland, while the $\mathrm{SADF}$, in principle, took responsibility for other front line states.

The government was dominated by the formidable State President, a bully but also a man with strong religious beliefs, who demonised, quite literally, what he called 'the enemy'. Interested in the prophecies of the great Afrikaner mystic 'Siener' Nicolaas van Rensburg, ${ }^{65}$ he believed that ultimately this enemy could be identified with international communism. He was so convinced of the imminence of a Soviet nuclear attack as to order the building of an underground nuclear-proof command bunker in the heart of Pretoria. Years later, after his old foe Nelson Mandela had been elected president, Botha told an interviewer:

There is a gradual buildup of two forces in the world. The one is the final return of Christ to this earth and the other is the eventual destruction of Satan himself. I told Mr Mandela when he came here ... "Mr Mandela, I warn you, these forces are going to destroy you". ${ }^{66}$

Botha's ministers, like Florentine courtiers, vied for the prince's ear. Foreign Minister 'Pik' Botha was widely distrusted by senior securocrats who suspected him of leaking information to curry favour with the US State Department. Some regarded him as little better than a traitor. Military men developed their own lines of communication with the US intelligence services and especially with William Casey, the anti-communist Director of Central Intelligence in Washington from 1981 to 1987.

The military, like the Police, developed specific underground warfare units. The most important of these was that commanded by the Chief of Staff (Intelligence), although the various armed forces - navy, army and air force - still retained their own intelligence services. The Chief of Staff (Intelligence) was a unit of the general staff of the SADF, directly under the head of the SADF. Until 1980, when he became Defence Minister, the head of the SADF was General Malan. He and President Botha soon developed the habit of confiding certain executive tasks to the Chief of Staff (Intelligence) with the result that the position, previously relatively obscure, became a very powerful one since it became divorced from the usual line function and devoted increasing attention to executing covert operations rather than simply gathering or coordinating intelligence. This had several effects which were to leave their mark on the history of South Africa. In the first place, the post of Chief of Staff (Intelligence) became coveted by ambitious officers, since it gave direct access to the head of the SADF and the State President, who seems to have regarded it as his personal operational arm. ${ }^{67}$ It also polluted the quality of intelligence since the politicisation of the office created pressures for intelligence estimates to be slanted for

65 Adriaan Snyman, Stem van 'n Profeet (Mosselbaai, Hugenote Publikasies, 1993), p. 16.

66 Quoted in Waldmeir, Anatomy of a Miracle, p. 43.

67 For an acid portrait of Lieutenant-General Pieter van der Westhuizen, Chief of Staff (Intelligence) from 1978 to 1985, see Chester Crocker, High Noon in Southern Africa: Making Peace in a Rough Neighbourhood (Cape Town, Jonathan Ball, 1993), pp. 116-117. 
political reasons rather than in conformity with the intelligence officer's ideal of impartiality. ${ }^{68}$ The number of employees of the office grew to hundreds or even thousands, some of whom had no background in any military corps. One officer described the change in personnel of the office of Chief of Staff (Intelligence) as follows:

Most of them are civilians, you see. They get a degree, and so on, and he joins the Defence Force and he puts on a uniform and now he's a colonel, or he's a major, or he's a brigadier, or he's a corporal, or whatever. But now he's got status. But he's not a fighter ... CSI is Intelligence, and being Intelligence they are always secret. And when you are secret you can do all sorts of weird and wonderful things without anybody knowing what you are doing. ${ }^{69}$

One section of the office of the Chief of Staff (Intelligence), known as the Directorate of Special Tasks, had the job of running allied armies in the front-line states, including super-ZAPU in Zimbabwe, UNITA in Angola, and RENAMO in Mozambique. After 1986 the Directorate of Special Tasks also developed liaison with Inkatha. In practice, the Chief of Staff (Intelligence) worked closely with Special Forces. This SAS-type arm, founded in 1974, was strengthened by an influx of Rhodesian special forces operatives recruited at the time of Zimbabwean independence in 1980.

Collectively, then, a number of covert units had a licence to break the law at home and abroad. Some, particularly those associated with the Chief of Staff (Intelligence), had political protection at the highest level in a chain of command which by-passed the conventional line of management, and all, in varying degrees, enjoyed opportunities to generate funds in the course of their work. The people manning these units were diverse. Some had largely civilian backgrounds, while others were veterans of wars in Rhodesia and elsewhere. In general, elite units such as Koevoet (Police) and the Reconnaissance Commandos (SADF Special Forces) enjoyed great prestige within the security forces. They developed a distinctive culture which was aggressive, arrogant and utterly contemptuous of the law and of civilians and even of ordinary soldiers or policemen. Such units tended to attract officers with disordered personalities, and long service in them brutalised otherwise unremarkable people.

Officers who had been trained in covert and often illegal work learned to interpret the wishes of politicians who spoke of 'eliminating' and 'taking out' activists, as Minister of Law and Order Adriaan Vlok often did, or of tracking down the enemy wherever he may be, as Minister of Defence Malan often urged. ${ }^{70}$ 'I support you in these things', Minister Vlok told a meeting of Security Police officers in 1990, referring to illegal activities, 'but you must know I would be committing political suicide if they ever came to light' ${ }^{71}$ His bluntness made Vlok popular among police officers. Eugene de Kock and other Vlakplaas operatives recall specific occasions on which Vlok and senior Police commanders joined in the drinking sprees and braais with which secret operators celebrated successful acts of illegal sabotage and murder such as the 1988 bombing of Khotso House, a Johannesburg office building housing a number of pro-ANC organisations. 'I was amused', De Kock told a court in 1996, 'because now we were talking about terrorism on home ground' ${ }^{72}$ The head of the SAP was later to confirm that the orders to bomb Khotso House came from President Botha. ${ }^{73}$ Members of special units interpreted the concept of total war quite

68 Ina van der Linde, 'Die Manne Agter die Skerms Dink Na', Vrye Weekblad, 25 November 1993; author's interview with Major-General Chris Thirion, Pretoria, 7 May 1996.

69 Ros Reeve and Stephen Ellis, 'An Insider's Account of the South African Security Forces' Role in the Ivory Trade', Journal of Contemporary African Studies, 13, 2 (1995), p. 233.

70 Laurence, Death Squads, p. 68.

71 Quoted in Taylor and Shaw, 'The Dying Days of Apartheid'.

72 Mary Braid, 'Apartheid's Assassin Accuses P.W. Botha', The Independent, 18 September 1996.

73 This was part of the testimony of General Johan van der Merwe to the Truth and Reconciliation Commission. See 'Can PW Be Forced to Speak, or Pay?', Weekly Mail and Guardian, 25-31 October 1996. 
differently from the more cerebral of the securocrats, for whom it was all about sublimating military activity and indeed every other branch of state activity to strategic political goals. For the rank and file of the special units, total war meant simply war without rules. None of the operatives seems ever to have imagined that one day they might be held to account for their actions.

The culture of cynicism and illegality penetrated very deep. One police unit, the Brixton Murder and Robbery Squad, developed a particularly sordid reputation for working in league with criminals, taking bribes and even carrying out criminal activities itself. Its members became used to enjoying the 'good things' in life: cars, expense accounts and, for the greedy, the opportunity to earn money on the side in lucrative black market deals. ${ }^{74}$ Officers of this unit were recruited en masse into the CCB, the Special Forces' own murder squad which functioned from 1986 to 1990 . Several were thereafter recruited by the Chief of Staff (Intelligence) to carry on the covert war against the ANC. Hence, at the lower end of the hierarchy, covert operatives could be criminals and could pass easily from one special unit to another, immersed in the common culture of violence and illegality. Ferdi Barnard, who worked for the Brixton Murder and Robbery Squad, the CCB and Military Intelligence, despite having served a prison sentence for murder, was described by his girl-friend as having become addicted to crack cocaine, which he traded with a senior officer of the Narcotics Squad of the Police. ${ }^{75}$ Another operative, a former Special Forces' soldier named Rich Verster, was commissioned in Military Intelligence immediately after serving a prison sentence.

The total strategy increasingly required covert operatives to set up front companies and adopt false identities. This is a form of subterfuge widely used by modern police forces in 'sting' operations in which the aim is to penetrate criminal circles by infiltration. It made its appearance in South Africa in the 1970s originally in connection with the government's efforts to promote propaganda overseas through the Department of Information. ${ }^{76}$ Secret servants working on international aspects of the total strategy, such as sanctions evasion, propaganda and intelligence gathering overseas, increasingly made use of this technique, setting up companies which appeared to have no connection with the South African government but which were in fact controlled by one or another covert unit. Running networks such as these required the export of funds from South Africa, which was often done illegally both to hide the true nature of the operation and to evade the South African government's own foreign exchange controls. The more intricate and large scale the financial manipulations became, the more even the South African Reserve Bank, internationally regarded as one of the few bastions of financial orthodoxy and professional rectitude on the African continent, became an accomplice to law-breaking. The Reserve Bank turned a blind eye to state-sanctioned illegality and provided financial succour to certain banks which had lost money in support of ventures which were more politically than commercially motivated. The Broederbond, via its influence in the Reserve Bank and Volkskas in particular, appears to have played a leading role in coordinating the upper levels of financial manipulation. ${ }^{77}$ White-collar criminals, such as the Pretoria lawyer Albert

74 Evidence of the corruption of the Brixton Murder and Robbery Squad was produced in court at the Pretoria trial of Charles Landman, former head of the unit, in 1996. Stefaans Brümmer, 'Tale of Top Cop's "Dicey Dealings" , Weekly Mail and Guardian, 6-12 December 1996.

75 De Wet Potgieter, 'Die Ferdi Barnard-Dossier', Rapport, 1 December 1996.

76 Mervyn Rees and Chris Day, Muldergate (Johannesburg, Macmillan South Africa, 1980).

77 Seegers, The Military in the Making of Modern South Africa, p. 286, note 16, remarks that the history of the Broederbond in the 1980s and 1990s is a subject in need of further study. See also 'Big Broeder Speaks', NoseWeek, 14 (March 1996), pp. 3-6. A rare study of the financial aspects of the total strategy, although it gives no attention to the role of the Broederbond, is Clive Scholtz, 'Drive Now and Pay Forever - the Apartheid Way', in R. Hengeveld and J. Rodenburg (eds), Embargo: Apartheid's Oil Secrets Revealed (Amsterdam, Amsterdam University Press, 1995), pp. 254-268. 
Vermaas, developed close relationships with leading politicians and securocrats whom they helped to organise the more intricate legal and financial aspects of front companies in banking and transport. ${ }^{78}$ The possibilities of making money from international fraud sanctioned by the South African state attracted the attentions of highly skilled professional criminals from abroad, even of at least one convicted Italian mafioso. ${ }^{79}$ Both these and more legitimate businessmen in search of government contracts developed close relations with securocrats and politicians whom they plied with gifts and invited to weekend braais and hunting-parties. ${ }^{80}$

During the 1980s, the number of front companies increased enormously. The SADF, via the Chief of Staff (Intelligence) and the Civil Cooperation Bureau (itself a front company), set up literally hundreds of front companies to carry out covert activities in fields such as peddling political influence, trading weapons and disseminating propaganda. Alongside the SADF-run front companies, there existed a number of state-owned companies, closely integrated into the security establishment, dealing with weapons research and development. Furthermore, ex-soldiers or retired officers of the Security Branch often set up private security companies unconnected to the SADF. A vast private sector arose, employing tens of thousands of people, consisting of either security companies or companies offering such mundane services as risk analysis, transport and so on, run by active soldiers working under cover, or by former security officers who, though no longer on the state payroll or subject to orders, retained contact with their old colleagues. This commercial-military complex became a fertile environment for covert operatives to do their work.

At the same time, after the mid-1980s, a number of elements converged to make the great network of covert units less coherent than they had previously been. The deployment of the SADF inside the townships greatly increased the likelihood of 'turf battles' between rival units, particularly of the SAP and SADF. Moreover, the destabilisation of the front-line states had had the effect of increasing the size of the informal economy on South Africa's own borders since the government of Mozambique, in particular, had virtually lost control of the usual instruments of formal economic policy. This provided new openings for South African covert units to gain influence by infiltrating smuggling and currencytrafficking activities of various descriptions.

The scale of the township uprisings of the mid-1980s persuaded some influential white South Africans, and eventually the government itself, to open discreet lines of communication with the ANC. The chairman of the Broederbond, Professor Pieter de Lange, had his first informal meeting with the ANC's Thabo Mbeki in 1986, and various businessmen and intellectuals also began to develop contacts with the ANC in exile, which the National Intelligence Service soon discovered and discreetly monitored. ${ }^{81}$ It was in this same period that the government began to develop its line of communication with the imprisoned Nelson Mandela. ${ }^{82}$ Although these communications remained shrouded in secrecy, rumours began to spread, particularly among those on the inside of the security establishment. A sense grew that change was in the air, and with it, some lower-level covert operatives began to suspect that if their political masters were changing tack, then those who moved at less exalted levels should take precautions of their own. In 1989, shortly before Namibia's independence, Eugene de Kock acquired from his old colleagues in

78 Regter L.T.C. Harms, Kommissie van Ondersoek na Sekere Moontlike Onreëlmatighede. Hoofverslag (Pretoria, Staatsdrukker, 1989). Vermaas, originally a lawyer to Department of Information chief Dr Eschel Rhoodie, was convicted by the Pretoria Supreme Court on 111 charges in December 1996.

79 Stephen Ellis, 'Africa and International Corruption. The Strange Case of South Africa and Seychelles', African Affairs, 95, 379 (1996), pp. 165-196.

80 De Wet Potgieter, Contraband: South Africa and the International Trade in Ivory and Rhino Horn (Cape Town, Queillerie, 1995), pp. 33-36, 178-182.

81 Sparks, Tomorrow Is Another Country, pp. 72-86.

82 Mandela, Long Walk to Freedom, pp. 609-668. 
Koevoet several truckloads of weapons from the stockpile of East Bloc arms which Koevoet had captured from SWAPO. He transferred these weapons to the Police farm at Vlakplaas, where he henceforth controlled his own private arsenal alongside the official one. $^{83}$

Although most securocrats remained unbendingly anti-communist, and hostile to the ANC, they could not fail to be affected by the changing international environment. The US government, after 1986, was moving towards a new understanding with the Soviet Union, and Pretoria's anti-communist position could no longer command the same support in Washington as it had done previously. A sure sign of this was the formidable squeeze applied to Pretoria by the US government during the negotiations which linked Angola and Namibia and led to Namibia's independence election in $1989 .{ }^{84}$ Given South Africa's increasingly precarious financial position, the Pretoria government could not resist pressure of this sort indefinitely. The beginning of the Namibian decolonisation process was the clearest sign to date to all South Africans that change was coming.

It was at this juncture that P.W. Botha was taken ill and the leadership first of the National Party, and later of the government, passed to F.W. de Klerk. De Klerk, on the conservative wing of the National Party throughout his career, never underwent a Pauline conversion. ${ }^{85} \mathrm{~A}$ skilled and intelligent politician, far more subtle than the bullying P.W. Botha, he was quick to detect that the combination of pressures on the government also constituted a major opportunity. His predecessor had begun negotiations with the ANC and had even entertained Nelson Mandela to tea at his official residence. To use a metaphor drawn from the quintessential Afrikaner game of rugby, the ball was passed to De Klerk, and he ran with it.

\section{Transition: the National Party Ascendancy}

'My God, he's got guts.' A senior securocrat, now retired from the army, recalls uttering these words when he sat watching television with other officials of the State Security Council secretariat on 2 February 1990. They were watching President De Klerk deliver the speech to the South African parliament in which he announced the unbanning of the ANC, the SACP and other proscribed organisations. ${ }^{86}$ De Klerk appears to have consulted no one, or almost no one, about his true intention. By springing such a surprise he was able to obtain for himself acres of political space and to win the international respect and even admiration which later qualified him for a half-share of a Nobel peace prize.

It appears that few in the security forces actively disapproved of De Klerk's move, followed as it was by the freeing of Mandela amid massive and unprecedentedly favourable media attention. The more thoughtful securocrats had always maintained that their struggle could be won only by political action, and they were realistic enough to know that the ANC had to play a part in this. Further down the hierarchy, seasoned covert operatives had seen enough twists and turns not to be surprised by anything which came their way. Many who had fought in Rhodesia and Namibia had become cynical about politicians. They had understood that ministers are sometimes obliged to say what they do not mean, and to will what they cannot say.

President de Klerk himself had never held a security portfolio, although he had attended most meetings of the State Security Council in the 1980s, and lacked the solid base in the

83 Author's interviews with Colonel Eugene de Kock and other members of Vlakplaas unit, Pretoria, May 1996.

84 Crocker, High Noon in Southern Africa, passim.

85 Wimpie de Klerk, F.W. de Klerk, the Man in His Time (Johannesburg, Jonathan Ball, 1991).

86 Author's confidential interview, Pretoria, 6 May 1996. 
security forces which his two immediate predecessors had both had. One of his chief assets in this rather forbidding environment was the support of the civilian intelligence agency, the NIS. This was itself the direct descendant of the former BOSS which had been thoroughly overhauled and was now manned by academics rather than policemen. Both directly and through the NIS, De Klerk enjoyed a close relationship with the Broederbond, the 20,000-strong secret society which still wielded immense influence among the Afrikaner elite and which in 1983 had been taken over by a reform-minded executive. ${ }^{87}$ The President authorised the NIS to spy on certain military and police units, with the result that NIS officers claim to have begun receiving a string of death threats. ${ }^{88}$

While no senior army or police officer would easily have contemplated countermanding a direct order from the government, the security services had become so powerful in three decades of war that they had abundant scope for feeding the Cabinet with information in a particular form and for interpreting instructions in their own way. Sparks mentions an early case which occurred within days of De Klerk's elevation to the presidency, when senior NIS officials who had set up their first formal meeting with the ANC in exile, anxious not to have the new President veto months of preparation, put a request for permission in such coded language that even De Klerk, a lawyer by training, did not realise what it was he was approving. The following text was placed before the State Security Council:

It is necessary that more information should be obtained and processed concerning the ANC, and the aims, alliances and potential approachability of its different leaders and groupings. To enable this to be done, special additional direct action will be necessary, particularly with the help of National Intelligence Service functionaries.

In accepting this, the President did not realise that he had just approved a face-to-face meeting between the NIS and the ANC. ${ }^{89}$

In similar vein, when a number of secret Strategic Communication (Stratcom) propaganda projects were presented to De Klerk by the Police, their bland descriptions disguised their full import. After a full review of covert projects in mid-1990, a number were approved for further implementation, including one involving payment of a Police subsidy to Inkatha. ${ }^{90}$ Far more than his predecessor, De Klerk kept his distance from the details of such covert operations, and he probably did not wish to know exactly what measures some of these entailed.

The most satisfactory explanation of the President's attitude is that, while he was determined to restore the authority of the Cabinet, he also fully intended that the security forces should maintain their grip over the country. In this, he had little room for maneouvre, since not only were the security forces the most powerful part of the state machinery, but Umkhonto we Sizwe and other opposition forces continued on a revolutionary footing, armed and dangerous. For the ANC until August 1990, negotiations were simply 'but another terrain of a number of interrelated terrains of our struggle', ${ }^{91}$ including notably the armed struggle. Nevertheless, in retrospect, De Klerk certainly missed opportunities, whether from insouciance, timidity or self-interest, we can only surmise, both to assert control over the murkier recesses of the security forces and to uphold the rule of law. In

87 Sparks, Tomorrow is Another Country, pp. 72-73.

88 Confidential source.

89 Resolution of State Security Council meeting no. 13 of 1989, quoted in Sparks, Tomorrow is Another Country, p. 111. The original would have been in Afrikaans.

90 Robert d'A. Henderson, 'South African Intelligence Under De Klerk', International Journal of Intelligence and Counterintelligence, 8, 1 (1995), p. 60; author's interview with officer of SAPS, Johannesburg, 2 May 1996.

91 Sechaba, 24, 4 (1990), p. 18. 
January 1990, when the President appointed Judge Louis Harms to head an inquiry into government death squads, its terms of reference were such as to minimise its possible effectiveness. Judge Harms was perhaps not the ideal choice if a truly penetrating inquiry had been intended. While many covert operators were amazed that the inquiry was instituted at all, since they had become accustomed to believe that they had absolute impunity, they soon realised its toothlessness. Many witnesses, by their own later admission, lied persistently to Judge Harms and even subjected his inquiry to ridicule. Several members of the CCB testified before him using pseudonyms and wearing dark glasses and false beards. The inquiry was ineffective in bringing death squads under the rule of law.

In an effort to impose his own control over the administration as well as to send a signal to the outside world on which he pinned such great hopes, De Klerk abolished the National Management System, the means by which security officers maintained oversight of the government at all levels through a parallel system of government, and replaced it with a National Coordinating Mechanism with much less power, ultimately responsible to a Cabinet sub-committee. ${ }^{92} \mathrm{He}$ abolished the State Security Council's powerful secretariat and made a real effort to reassert the paramountcy of the traditional form of cabinet government, which seems to have weakened the coordination of military and political activity.

Government strategists were applying to South Africa some of the conclusions they had drawn from the decolonisation process in Namibia, where the SWAPO share of the vote had been whittled down from somewhere over 70 per cent to just 55 per cent in barely 6 months. This had been achieved by massive and coordinated covert activity including funding of opposition parties, dissemination of propaganda, the creation of covert media organisations and the intimidation of voters, notably by keeping the ferocious Koevoet unit deployed in the field until the eve of balloting. ${ }^{93}$ All this had been carried out despite the presence of United Nations monitors and an influx of foreign journalists and observers. It is significant that the military campaign to influence the results of elections in Namibia is alleged to have been overseen by General 'Kat' Liebenberg, a former Commanding Officer of Special Forces who was to head the SADF during the first part of the transition to democracy in South Africa itself.

Many government strategists concluded that similar techniques, if applied over years rather than months, could be even more effective in South Africa. The calculation of the most influential National Party leaders was that, if the transition were protracted, it might even allow the National Party time to form a right-of-centre alliance, in company with Inkatha and a number of minor parties and conservative homeland leaders, which could beat the ANC at the polls. Dr Gerrit Viljoen, Minister of Constitutional Development in the first De Klerk cabinet and a past chairman of the Broederbond, was a leading advocate of this strategy. In March 1990, after describing apartheid as a theory that 'didn't work', Viljoen continued.

And that is why we went to the electorate and said: 'We want to change our approach completely. We want to include blacks as fellow citizens ...'. The whole approach of the government is to shift the emphasis from race to quality of government and the broadening of democracy, in spite of the risks. ${ }^{94}$

92 Anton du Plessis and Mike Hough (eds), Selected Official South African Strategic Perceptions, 1989-1992 (Institute for Strategic Studies, University of Pretoria, Ad hoc publication no. 29, 1992), pp. 1-10.

93 Sparks, Tomorrow is Another Country, pp. 154-155.

94 Interview in The Star, 17 March 1990. A Broederbond document setting out a similar line of thinking is 'Basic Political Values for the Survival of the Afrikaner' [English translation], copy in Box 11.2, Institute voor Zuidelijk Afrika, Amsterdam. This document was first circulated for internal discussion in the Broederbond in 1986. 
This would be achieved, Viljoen maintained, not through universal adult suffrage in a unitary state, but by negotiating full citizenship rights for all in a constitution with strong guarantees for minority rights and a powerful second chamber. We may note, furthermore, that the idea that the National Party could redefine itself 'as the core of a substantial multi-racial conservative alliance' was one which was being mooted by some influential academics at the time. ${ }^{95}$

The strategy of building a multi-racial political alliance opposed to the ANC/SACP depended crucially on Inkatha. The latter, technically a cultural organisation which turned itself into the Inkatha Freedom Party (IFP) in 1990, was the only political party with which the National Party could reasonably hope to build an alliance which both commanded substantial support among black voters and had a strong regional base. Although ANC supporters tended to represent Inkatha as simply a puppet of the apartheid state, it is relevant to recall that Inkatha could claim a long historical pedigree and consistently demonstrated its ability to mobilise considerable numbers of supporters. In Chief Mangosuthu Buthelezi it had a leader who, at least until the emergence of the Transkei's General Bantu Holomisa as an ally of the ANC in the late 1980s, had been more successful than any other homeland leader in asserting his own autonomy. The intensification of armed struggle in the 1980s had pushed him ever closer to the security forces upon which he relied for military assistance against Umkhonto we Sizwe and the ANC-supporting young comrades in Natal.

In many ways the securocrats' military training and culture were ill-adapted to the emerging rules of the political game. One senior securocrat recalls his dismay when he realised just how little value De Klerk attached to long-term planning after the President had admitted that he had no idea in what position the government would be six months hence. ${ }^{96}$ In this respect De Klerk was a pure politician, with none of the inflexibility or near-military thoroughness of his predecessor. It was a clash of cultures between the military code - disciplined, hierarchical, averse to risks - and a view of politics as the art of the possible. No doubt many securocrats, like most people in similar circumstances, resented their own loss of influence under De Klerk and were dismayed by the prospect of losing power. Lower down the security hierarchy, some covert soldiers, having been trained to fight the ANC and SACP enemy, assumed that they would continue to do this unless explicitly told by their commanders to do otherwise in terms which brooked no misunderstanding or evasion. Politics was not their business, and middle-level operatives appear to have believed that, if the rhetoric of the government had changed under De Klerk, this was simply in keeping with the current phase of the struggle: the politicians' task was to make political capital out of their continuing military activities. Eugene de Kock recalls noting how the 'politicians talk peace in the newspapers', but that 'amongst the forces there was a culture of resistance. It came from the top' ${ }^{97}$ Even after the unbanning of the ANC, De Kock's unit was kept on full alert and fully armed. By mid-1990, he had more than 300 askaris under his command. In July 1990, working with the chairman of the Inkatha Youth Brigade in the Transvaal, Themba Khoza, who was on the Vlakplaas payroll as a police informer, De Kock began selling guns to the pro-Inkatha inhabitants of hostels on the East Rand where local tensions ran high. This was to spark some years of strife on the East Rand which turned some areas into veritable war zones. De Kock claims that he carried out some offensive actions of this sort on his own authority, and others under direct orders. ${ }^{98}$

95 Hermann Giliomee and Lawrence Schlemmer, From Apartheid to Nation-Building: Contemporary South African Debates (Cape Town, Oxford University Press, 1989), p. 200.

96 Author's interview with Major-Gen. Tienie Groenewald, Pretoria, 19 May 1996.

97 Interview with Colonel Eugene de Kock by Phillip van Niekerk, Pretoria Central Prison, 18 February 1996.

98 Author's interview with Colonel Eugene de Kock, Pretoria Central Prison, 4 May 1996. 
One former resident of the C 10 farm at Vlakplaas which De Kock commanded recalled the atmosphere at the base during 1990. Day after day, groups of askaris would leave by car to sow mayhem at taxi-ranks and among the public generally. ${ }^{99}$ Returning from their grisly work to the farm at Vlakplaas, the askaris held parties and drinking-bouts long into the night. It was also in mid-1990 that the train massacres began. Former members of the SADF's 32 Battalion were later to seek indemnity from the Truth and Reconciliation Commission for their role in train attacks, and there is evidence that some such attacks may have been the work of Five Reconnaissance Commando, which had worked closely with RENAMO in Mozambique. ${ }^{100}$ RENAMO had demonstrated that random killings of this sort had a powerful psychological and political effect. In this case they demonstrated that the ANC's claim to have won the struggle was hollow since it was unable to protect its own supporters and future voters. It became suicidal to wear an ANC tee-shirt in some townships and the ANC's capacity to organise was seriously disrupted.

The assertion by certain senior police officers that they were unaware of De Kock's covert warfare from 1990 to 1993 does not stand up to examination. ${ }^{101}$ Since 1989, when the Vrye Weekblad newspaper carried its first interview with Captain Dirk Coetzee, one of De Kock's predecessors as commander of the Vlakplaas unit, the whole of South Africa had been able to learn De Kock's name and the function of his unit. And yet his superior officers did nothing to prevent him from continuing in his special field of murder on a larger scale than ever. Officially the Vlakplaas unit was reorganised in 1991 and redeployed to investigate the weapons trade, but this simply provided a perfect cover for selling guns to Inkatha while making money into the bargain. Former members of the unit have described how they would cache guns from De Kock's private arsenal, 'discover' them the next day, and then receive a police reward. When interviewed by the present author, Police Commissioner General Johan van der Merwe was unable to account for how De Kock was able to continue the nefarious activities which made him a mainstay of the Third Force while he was allegedly being 'closely supervised', in Van der Merwe's words, by several Police generals. ${ }^{102}$ There is every reason to concur with Judge Goldstone's later conclusion that certain Police generals were accomplices to Third Force activity carried out by De Kock's unit, ${ }^{103}$ which is what De Kock himself also maintains.

Both the Police and Military Intelligence operated programmes of military and financial aid to Inkatha, and key Inkatha personnel were on the security forces' payroll. While leaders of the ANC were now frequenting ministerial suites and conference rooms, middle-ranking ANC officials were extremely vulnerable, and many were killed in the burgeoning violence, in some cases the apparent victims of planned assassinations. At the same time, the ANC was inflicting casualties on its own enemies, most notably in Inkatha, which lost almost 300 office holders to violent attack between 1985 and $1993 .{ }^{104}$ The Police too were under assault as never before, losing hundreds of officers to acts of violence. Ordinary police officers who risked their lives in war-zones on the East Rand and

99 Author's interview with Peter Casselton, Pretoria, 19 May 1996.

100 On 32 Battalion, see Peta Thornycroft and Eddie Koch, ' 32 Battalion to Come Clean on Train Violence', Weekly Mail and Guardian, 29 November-5 December 1996; on Five Recce, see the testimony of Felix Ndimene, 'Confessions of an SADF Killer', New Nation, 26 July-1 August 1991, pp. 6-7. A chronology of the train violence is Independent Board of Inquiry, 'Blood on the Tracks: a Special Report on Train Attacks by the Independent Board of Inquiry', (Johannesburg, mimeo, undated).

101 Pauw, 'Prime Evil'.

102 Author's interview with General Johan van der Merwe, Pretoria, 21 May 1996.

103 'Interim Report on Criminal Political Violence by Elements within the South African Police, the Kwazulu Police and the Inkatha Freedom Party', by the Commission of Inquiry regarding the Prevention of Public Violence and Intimidation, 18 March 1994. Available at HURISA, Sandton.

104 Kane-Berman, Political Violence in South Africa, p. 25. 
elsewhere, without themselves being party to any covert activity, naturally enough resented being labelled as instigators of violence by opponents of the government.

Like the security forces, the ANC did not in fact cease its armed struggle in 1990. It was continuing to send personnel abroad for military training and it was smuggling arms into the townships. ANC leaders admitted that they could not always control their own supporters. After the outbreak of the war on the East Rand, the organisation devoted considerable attention to organising Self-Defence Units and arming its supporters there and in other conflict zones. When, in July 1990, the Police discovered Operation Vula, a sophisticated undercover network for arms-smuggling and guerrilla warfare dominated by the SACP, the securocrats accused the ANC and the SACP of negotiating in bad faith and secretly putting in place a network aimed at the armed seizure of power. ${ }^{105}$ No professional security officer would cease to be vigilant or would contemplate disarming as long as there was a chance of the opposition launching an offensive.

In short, the security forces were not alone in perpetrating violence in 1990-1994. Nevertheless, both written and oral sources and analyses of the statistics of violence lead to the conclusion that covert units of the state and its Inkatha ally were the main aggressors. In general, the violence of the period is best understood as an intensification of the existing campaign of low-intensity warfare. ${ }^{106}$ After mid-1990 it was clear that the unbanning of the ANC had led not to peace, but to a change in the unwritten rules of engagement. South Africa is not the only country in the world where revolutionary struggles have been accompanied at various stages by intensive negotiation. In a contest of this sort, proponents of violence and of peace may exist within the same organisation and the preponderance of one or the other mode of operation may reflect the outcome of factional struggles within the various parties to the conflict as well as between protagonists. Partly for this reason, disclosure, publicity and the quality of media representation can become crucial elements in political-military struggle. Indeed, one of the skills of covert operatives on both sides was to organise their military activities in such a way as to appear to the black South African public as winners while appearing to the international and white South African publics as the innocent party in the war, the one reacting to aggression. Political leaders in these circumstances strive to turn military gains into solid political capital, and in the process to rein in those within their own ranks who are the strongest advocates of military methods. Conversely, perpetrators of violence sometimes intend not just to inflict damage on the enemy, but also to use violence as a means of securing advantage in inner-party factional struggles.

The National Party, the ANC, Inkatha and probably every other main actor understood well the nature of this contest. In each of these organisations there were struggles between advocates of peace and proponents of violence. According to Chris Hani:

It is our conviction that the National Party government is pursuing a twin-track strategy. This strategy involves negotiating with its major political opponent, the ANC and allies, and at the same time deliberate destabilisation, including violent destabilisation of our forces. ${ }^{107}$

This was an accurate description of what the government was doing. It was also an accurate description of what the IFP and the ANC were doing. Moreover there were plenty of freelance operators, professional criminals and others, or rival armed groups from the

105 On Operation Vula see Connie Braam, Operatie Vula: Zuidafrikanen en Nederlanders in de Strijd Tegen Apartheid (Amsterdam, Meulenhoff, 1992); also Robert d'A. Henderson, 'Operation Vula against Apartheid South Africa: a Case Study in Sub-State/Insurgent Intelligence Activities', awaiting publication.

106 Mark Shaw, 'South Africa's Other War: Understanding and Resolving Political Violence in Kwazulu-Natal (1985-?) and the PWV (1990-?)' (unpublished PhD thesis, University of the Witwatersrand, 1997), pp. 210-230.

107 Chris Hani, 'Just How Possible Is Peace?', The African Communist, 130 (1992), p. 8. 
Afrikaner Weerstandsbeweging (AWB) to the Azanian People's Liberation Army (APLA), who were taking advantage of the circumstances to launch campaigns of their own. The existence of various security forces established by the state, such as homeland armies and police forces, the National Peacekeeping Force, and the Internal Stability Unit of the Police, further complicated the politics of security and coercion.

The Vlakplaas unit was by no means the only covert unit which was still centrally involved in violence against the ANC on behalf of the state, or in other words which constituted the Third Force, and it was probably not even the most important of them. Curiously enough, the best-known of the military death squads, the Civil Cooperation Bureau (CCB), was responsible for relatively few murders inside South Africa. The CCB was never a very significant force inside the country since its mandate specifically charged it with working abroad. (Hence the deviousness of the terms of reference of the Harms commission, which empowered Justice Harms to study only death squad activities inside South Africa!) After the CCB was disbanded in 1990, many of its former members joined other covert units. The most important of these was the office of the Chief of Staff (Intelligence). During the previous decade, this had become the richest and most influential of all covert units, with an awesome offensive ability and experience in destabilisation as well as an intelligence-gathering network at home and abroad. After 1990, many Military Intelligence projects were being carried out by front companies, like International Researchers in the Ciskei homeland. Within the office of Chief of Staff (Intelligence), the Directorate of Special Tasks, the unit which had overseen destabilisation campaigns abroad, was in charge of a special project of support for Inkatha known as Operation Marion. Another section of the office of the Chief of Staff (Intelligence), the Directorate of Covert Collection, was running both offensive and information-gathering projects including specific anti-ANC programmes. Operation Marion is known to have been approved by the State Security Council, and many other projects too were approved in principle at the highest level, at least until 1991. Such veteran securocrats as Adriaan Vlok and General Magnus Malan still retained security portfolios and Malan, in particular, carried great weight in the Cabinet until his demotion in July 1991. One member of the cabinet recalls De Klerk challenging these two without success:

Every time we would discuss it, they would try to convince us that there was no third force. I was present several times when De Klerk challenged first Vlok and Hernus Kriel. He said to them, "But how do you explain this?" He really got into them. But they always had very convincing answers. I think it was a question of trusting the people who advised him. ${ }^{108}$

Waldmeir comments, rightly, that 'De Klerk's concern for stability was a convenient excuse for doing nothing. He seems to have chosen to remain in a state of negligent ignorance rather than face the impossible choices with which knowledge would confront him. ${ }^{, 109}$ The veteran covert operative, Craig Williamson, made the same point about De Klerk more harshly: 'He either misunderstood entirely the nature of the machine at his disposal, the machine he was running, or he was deliberately closing his eyes, or he's a liar'. ${ }^{110}$

Until this period, the government as a whole, including the State President, was willing to allow covert war to be waged on a substantial scale provided only that ministers could not be personally held responsible. They did not wish to be informed precisely about what happened on the ground. Given the general atmosphere of violence, it did not require much imagination to suppose a connection between secret projects, no matter how bland their formal description, and the waging of war at ground level. The danger to South Africa was that if the National Party persisted in protracting the transition, particularly if it also

108 Anonymous, quoted in Waldmeir, Anatomy of a Miracle, p. 186.

109 Ibid., p. 186.

110 Undated press clipping. 
allowed covert units to continue making war on the ANC with little check, violence could gain such momentum as to destabilise the political situation entirely.

By early 1991, the government appeared to believe that it was succeeding in its strategy of surreptitiously attacking its enemy while consolidating its political position. De Klerk's international standing was higher than that of the head of any South African government for 50 years. However, the government had to pay a price for its continuing sponsorship of covert warfare. In the first place, the high incidence of violence and the widespread belief among many black South Africans that covert units of the security forces were implicated led to the erosion of the substantial credit which De Klerk had acquired among some sections of the black community, thus limiting the likelihood of the National Party successfully redefining itself as a non-racial party, as it hoped to do. At the same time, his unwillingness or inability to limit these activities suggested to some that he was not in fact in total control of government policy. In other words, the covert use of state violence, rather than projecting an image of strength calculated to cow the population, could also create an image of weakness which had exactly the opposite effect. It undercut rather than complemented the National Party's longer-term political strategy.

\section{Transition: the Eclipse of the National Party}

In July 1991, the Johannesburg Weekly Mail \& Guardian and the British Guardian newspaper simultaneously revealed the existence of a secret Police project for funding Inkatha. This dealt a major blow to De Klerk's prestige both at home and, perhaps even more significantly, abroad, where he had been almost entirely absolved from blame for any of the violence until this point. The ANC was eventually to seize the advantage in political negotiations largely as a result. In retrospect, National Party leaders may feel that they overplayed their hand in 1990-1991, and failed to capitalise on their political supremacy at that point. That is certainly the view of many former security force commanders, who point out that in that period a total amnesty for security force personnel was on offer but was rejected by an over-confident Cabinet. ${ }^{111}$

In response to the Inkathagate revelations, De Klerk reshuffled his two leading security ministers, Malan and Vlok, and on 30 July 1991 the President ordered a new review of secret projects, known as the Khan Commission. Although the Khan report has never been published, it is known to have investigated at least eleven projects run by the Department of Foreign Affairs, sixteen by the SADF, nine by the Police and seven by the NIS. The Khan commission is said to have noted that the official descriptions of some projects were bland in the extreme and that some were used to 'piggyback' other operations. For example, one SADF operation known as Project Echoes was officially 'aimed at combatting verbal attacks on $[\mathrm{SADF}]$ duties and functions. Activity relates to the acquisition of information in relation to MK [Umkhonto we Sizwe] mainly and passing this to the media' ${ }^{112}$ Project Echoes was later revealed to have made use of violence, blackmail and other illegal means. After failing to secure from his senior Police officers an assurance that no further leaks would take place, De Klerk ordered the termination of a number of projects deemed to be of an offensive nature. But he also approved the recommendation of the Khan Commission that certain covert activities, including the SADF's Project Echoes, should continue. The new Law and Order minister, Hernus Kriel, took a largely hands-off approach to his department, clearly unwilling to risk being compromised but also unwilling to purge covert operatives. Again according to De Kock, police chiefs interpreted the government's

111 Author's interviews, Pretoria, May 1996.

112 Confidential source. 
distinctly ambiguous signals to mean that they should carry on making war on the ANC but not expect any political cover. There is evidence to support this account as, despite the notoriety of his unit and the continuing violence in the country, and despite being under the 'close supervision' (in the words of the Commissioner of Police) of Police generals, nothing substantial was done to close down De Kock's activities.

The more the Cabinet distanced itself from the covert units, the more the latter used their own initiative. Some covert operators set up informal connections. De Kock, for example, had many acquaintances in Special Forces and in Military Intelligence, as well as in the network of arms companies run by the state-owned arms manufacturer ARMSCOR, and he would meet them from time to time without informing his superiors. He and other covert warriors met frequently at a brothel in Johannesburg run by Military Intelligence as part of Project Echoes. The official function of the brothel was described by its managers as being to provide a safe-house where security specialists could meet each other and could talk to ANC contacts and informers under cover. ${ }^{13}$

The longer the transition lasted, the clearer it became that the days of the National Party government were numbered. It lost that most important and intangible political asset, authority. Beset by problems of this nature, and under pressure from white conservatives to the right of the National Party, in March 1992 De Klerk held a referendum of the white electorate in which he sought a vote of confidence to continue the negotiating process. $\mathrm{He}$ misinterpreted the handsome victory which this brought him, evaluating it too much in terms of the old white politics. De Klerk hardened his attitude at the constitutional negotiations known as the Convention for a Democratic South Africa (CODESA), begun in December 1991, which soon broke down in consequence. ${ }^{114}$ Some hitherto optimistic commentators and by-standers began for the first time to wonder whether the whole transition process might not collapse irretrievably, and to speculate whether there were not people within the security forces who intended precisely that.

In the absence of negotiations, both sides resorted to demonstrating their strength in the ways they knew best. The ANC declared a campaign of 'rolling mass action', a series of demonstrations which in the circumstances were bound to lead to violence but which were the best available way of demonstrating the size of its support. Then, on 17 June 1992, some people from a migrants' hostel at Boipatong, south of Johannesburg, attacked a pro-ANC township and killed 38 men, women and children during the night. There was an immediate recognition that this massacre was distinctive, not only because of its large scale. Local people were convinced that it was the work of the security forces, and there is circumstantial evidence that it was indeed the work of one or other of the covert units. Above all it took place at a time when negotiations were suspended, on the day after the anniversary of the 1976 Soweto rising. If it was indeed organised by one or other of the state security forces as appears most probable, it was clearly intended as a provocation to the ANC. This is how the ANC interpreted it, and ANC hardliners in their turn canvassed the possibility of what some termed 'the Leipzig option', a reference to the vast demonstrations which had only recently brought about the collapse of East Germany.

It is ironic that the term 'Leipzig option' was used by some people previously noted for their uncritical admiration of the East German government. Among these was Ronnie Kasrils, the former head of Umkhonto we Sizwe Military Intelligence and a leading ANC/SACP radical. When, on 7 September 1992, Kasrils led some 80,000 people in a march on Bisho, the capital of the Ciskei homeland whose government was under the effective control of Military Intelligence, another major massacre occurred. Over 28 people

113 See articles by De Wet Potgieter in Rapport, 1 December 1996. Also see Pauw, 'Prime Evil'.

114 Sparks, Tomorrow Is Another Country, pp. 133-134. 
died as Ciskeian security forces fired into the crowd. The South African press attached a large part of the blame to Kasrils's cavalier attitude. ${ }^{115}$ The Bisho massacre brought all of South Africa's major politicians to the realisation that they were staring into an abyss of violence.

To judge from his actions over the next three months, President de Klerk was one of those who recognised just how acute was the danger now faced not just by his government, but by South Africa as a whole. So far had his authority diminished that he now needed the ANC, and particularly the personal support of Mandela, to support the writ of the state and to prevent a slide into anarchy or even civil war. But to secure Mandela's support required a fundamental change in National Party strategy, which had previously been based on the notion of eroding the ANC's power and building an alliance with Inkatha. After the Bisho massacre, the government's whole political strategy was comprehensively and rapidly switched. On 26 September 1992, the National Party and the ANC signed a Memorandum of Understanding which implicitly confined Inkatha to the margins. The National Party's chief negotiator was Roelf Meyer, one of a younger generation of National Party leaders who could hope to continue their careers into a democratic future and who favoured working with the ANC towards a new dispensation. This is a good example of the way in which highly symbolic acts of violence, like the Bisho massacre, could substantially alter the balance of forces not just between rival organisations, but also between factions and generations within one party.

De Klerk, now siding with Meyer and the new generation in his party, took real steps to rein in the Third Force. Already, in August 1992, the President had retired a number of senior Police officers in a move interpreted as an attempt to assert his authority over the force. In October 1992, the powers of the Goldstone Commission were strengthened and the following month, Goldstone's investigators discovered a Military Intelligence safe house in Pretoria, with proof that offensive operations against the ANC, including Project Echoes, were still in force. The State President immediately appointed the SADF Chief of Staff, Lieutenant-General Pierre Steyn, to investigate the armed forces. It is probably no coincidence that at the same time, Eugene de Kock was approached by his superiors and asked to resign from the police force pending negotiations over severance pay.

General Steyn's report to De Klerk remains shrouded in mystery. Steyn himself came under considerable pressure from fellow officers as he went about his investigation; his house was broken into by persons unknown. There has been much speculation as to the exact form his report took. He is said to have briefed the State President on the basis of a series of written reports rather than to have handed over a finished document. He communicated the names of officers considered to have some connection to Third Force activity, but whether he did so verbally or in writing is unclear. In December 1992, shortly after receiving Steyn's briefing, De Klerk fired 23 officers, including two generals. ${ }^{116}$ Among those dismissed were the deputy Chief of Staff (Intelligence) of the SADF and the chief of the Directorate of Covert Collection. Some of those fired protested their innocence, claiming they were the victims of bureaucratic intrigues orchestrated by the NIS, which they thoroughly distrusted. Although much remains to be known about this episode, the drift was plain: De Klerk had now hitched the National Party to the ANC and was demonstrating his determination to act against covert units which had constituted the Third Force and which had until now been making war on the ANC. The most careful analysis made so far of violence

115 Ronnie Kasrils, Armed and Dangerous: My Undercover Struggle Against Apartheid (Oxford, Heinemann, 1993), pp. 354-368.

116 Howe, 'The South African Defence Force and Political Reform', pp. 39-41. 
statistics indicates that, whereas the level of political violence rose steadily until 1994, the types of attack most characteristic of hit-squads declined after mid-1992 when De Klerk began to exert control over the covert units. ${ }^{117}$

One clear implication is that De Klerk could have taken similar action at any time during the previous three years, difficult though this may have been. By failing to assert his authority decisively over covert operatives until late 1992, and in fact by previously approving offensive operations such as Project Echoes, euphemistically described as Strategic Communication projects, De Klerk had contributed to the weakening of his own government's authority and had committed himself to a political-military approach which turned out to be ineffective in securing the government's strategic goals. Foreign governments and local business leaders increasingly saw the government's weakness as the greatest threat to stability and were inclined to modify their own positions accordingly. The ANC, after an initial period of disarray, considerably sharpened its negotiating strategy at the reconvened constitutional negotiations known as CODESA 2, where the formidable Cyril Ramaphosa emerged as the chief ANC negotiator. Ramaphosa and his team, including Joe Slovo, Valli Moosa, Mac Maharaj and others, demonstrated a greater skill than government negotiators in turning events on the ground into political capital.

All of this left the commanders of the armed forces in a difficult position. Officers who had been trained for years to believe that they were fighting a war against communism and subversion, some of whom displayed the hubris of those grown accustomed to power, now saw the ANC heading inexorably towards government. Communication between senior officers and their political masters was extremely poor as the successive ministers of the Police and of Defence who replaced Vlok and Malan after July 1991 either distanced themselves from their porfolios or were simply unable to impose themselves on their officials. Many senior military and police officers by this time had utter contempt for De Klerk and his ministers.

But no matter how much they resented this turn of events, and even if they believed it was their patriotic duty to act against the ANC on behalf of white South Africa or, more precisely, the Afrikaner volk, senior military commanders were too experienced, after 30 years of war, to believe that violence alone would solve their problem. It is perhaps for this reason, as well as for reasons of professional self-esteem, that no serious plan for a coup d'etat is known to have existed within the SADF at any stage, although there were certainly rumours of such. There was no organisation to the right of the National Party with the ability to contest the political ground where the struggle had to be fought. Some former securocrats who had retired from active service tried to build right-wing parties and homeland governments into a grand anti-ANC alliance, most notably in the form of the Concerned South Africans Group (COSAG), and some ex-generals remained in close touch not only with each other but with former colleagues who were still serving in the security forces. Using these contacts, Inkatha began building a major private army, using game parks for training purposes.

As the government grew weaker, the armed forces emerged clearly as the single most powerful bloc in the country. Aware that they could not rely on the political support of more than a small minority of South Africans, the commanders of the SADF nevertheless headed a coherent organisation possessed of a massive capacity to make war. Generally speaking, the generals adopted a low political profile. Their rare public pronouncements, particularly by the shrewd Army chief, Lieutenant-General Georg Meiring, who took command of the SADF in 1993, were generally limited to utterly fallacious but politically meaningful comments that the SADF was a Western-style force which eschewed politics

117 Shaw, 'South Africa's Other War', pp. 210-230. 
and served the government of the day. Such comments, although superficially banal, signalled that the SADF could be prepared to accept the constitutional change now taking shape, which would inevitably bring the ANC to power. It is known that after mid-1992 senior SADF commanders, including the Chief of Staff (Intelligence), had a series of discreet bilateral meetings with leaders of the ANC and its armed wing Umkhonto we Sizwe. ${ }^{118}$

SADF generals could be confident of the discipline of their forces, although most seem to have been convinced that the SADF would never obey an order to open fire on white protestors or paramilitaries. Although the SADF could not assert direct control over white civilians, including former Permanent Force members, and could only with difficulty exert influence over members of the Citizen Force when these were not in uniform, SADF commanders nevertheless occupied a strategically vital position. The force continued to benefit from the general respect of the white population, so many of whom had performed national service in its ranks, and to represent the ultimate guarantee against anarchy or unrestrained communist or black government. Covert warfare units abounded inside the SADF, and related networks existed in the Police and among white extremists and their allies generally. If the leadership of the SADF were to cut off all links with these covert operatives, it would find it impossible to control them at all. Eugene de Kock, for example, who resigned from the Police in April 1993, continued to supply arms to Inkatha, with the apparent cooperation of businessmen working for military front companies and other military-run companies. He set up his own private weapons-trading company which immediately became the hub of yet another Third Force-style network. The Third Force broke up into smaller units which were increasingly independent of any central line of command, although individuals were able to communicate with each other via informal channels.

The risk this presented became clear in April 1993 when a group of right-wing conspirators murdered Chris Hani, bringing the country to the edge of disaster once more. It was in these circumstances that General Constand Viljoen, a former commander of the SADF, probably white South Africa's most respected soldier, made a spectacular arrival on the political scene, leaving retirement on his farm with a public promise to lead the right wing. He was supported by Eugene Terreblanche, leader of the Afrikaner Weerstandsbeweging (AWB), who pledged his troopers to the service of Viljoen's Afrikaner nationalist Volksfront. The threat from this source was at its greatest in March 1994, when Viljoen encouraged AWB paramilitaries to travel to the homeland of Bophuthatswana to defend the homeland's anti-ANC president, Lucas Mangope, against a popular uprising. But Terreblanche's men were an undisciplined and ineffective rabble who withdrew in disorder after some of their number had been killed, in view of television cameras, by soldiers of the Bophuthatswana Defence Force. Viljoen distanced himself from the AWB. The Battle of Bop, as it was known, probably marked the closest point to civil war reached during South Africa's transition.

In retrospect, Viljoen's role in the last year of the National Party government may be seen to have been an historically important one in the sense that, while he consistently argued the cause of a self-governing boerestaat, he nevertheless kept a significant section of the far right on the constitutional path and eventually participated in the April 1994 elections. Although General Viljoen has denied having orchestrated his plans with the leadership of the SADF, ${ }^{119}$ a question remains as to whether serving officers, desperate

118 Jacques Pauw and Shaun Johnson, 'MI Chief's Secret Parley', The Star, 27 August 1992; Mark Shaw, 'Negotiating Defence for a New South Africa', in Jakkie Cilliers and Markus Reichardt (eds), About Turn: the Transformation of the South African Military and Intelligence (Halfway House, Institute for Defence Policy, n.d.), pp. 9-34.

119 Author's interview with General Constand Viljoen, Cape Town, 27 May 1996. 
to prevent a civil war after the April 1993 murder of Hani, prevailed upon him to take the leadership of the extreme right which was threatening to plunge South Africa into chaos.

After 1992, then, the commanders of the SADF, who had wielded such great power in government since the late 1970s, had become the essential arbiters of whether the country would have all-out war or elections and something resembling peace. The generals, as Afrikaner nationalists and as veterans of three decades of war, were no doubt disappointed by many aspects of the emerging constitutional settlement, but on balance it was one they could tolerate. It required considerable political skill, in a situation where large numbers of complex informal relations existed both within and outside the armed forces, to impose this view on the wilder right-wing elements who were pushing for the unilateral declaration of a white homeland, a boerestaat. The full details of whatever discreet contacts took place between the leaders of the SADF, the leaders of the ANC, and the far right which, after May 1993, was grouped around a former head of the SADF, General Viljoen, remain unknown. But it can be said that Viljoen's role was crucial in bringing the country through the elections of April 1994. The new President, Nelson Mandela, recognised in Constand Viljoen something of a kindred spirit, a nationalist and a fighter with a reputation for personal integrity. The two men, the icon of black liberation and the last of the oldfashioned Boer generals, became close.

\section{The Splintering of the Third Force}

The name 'Third Force' is in many ways a misnomer, implying as it does an autonomous force situated between the ANC and the National Party. In reality, the Third Force, in the sense of a nexus of SADF and Police units experienced in covert warfare, was originally organised by the state itself, coordinated in the National Management System through a dense network of committees, and continued to have a recognisable degree of central coordination until late 1992.

The name 'Third Force' was often used by the mainstream media in the period of transition vaguely to designate a group of semi-independent operators who sought to sabotage negotiations through the escalation of violence. Some individual officers may have had this in mind, particularly those below the top level, but it is not a convincing explanation of the motives of those senior SADF and Police commanders, and their political masters, who at least permitted them to perpetrate violence in South Africa in the early 1990s. The evidence contained in the present article suggests that the Third Force was organised from a very high level, certainly until 1989, after which its senior command and control system were gradually eroded until 1992. Thereafter it was effectively privatised. It cannot be considered to have been independent of the National Party government itself. We might add that the most senior people who can be said to have constituted the Third Force, or who at least encouraged it to operate, did not actually wish to halt negotiations entirely.

Middle-ranking officers like Colonel Eugene De Kock and Colonel Joe Verster, the managing director of the CCB, saw themselves as warriors, professionals who had been trained to attack the enemy until unambiguously ordered to stop. They had been brought up to believe that to fight for volk and vaderland was their highest duty. Throughout careers spent in underground warfare they had learned the arts of camouflage and subterfuge which meant that even disbanding their units was not taken as an unambiguous signal to disarm. They had seen too many ruses of this sort to take them at face value. Many covert warriors had developed a financial interest in war, and this was an incentive to continue. In the last few months of the National Party government many opened informal channels to the ANC, hoping for amnesty under a new government or even reinstatement 
in the security forces. But, until the end, both the SAP and the SADF remained coherent organisations, and hence it was the senior officers whose views counted most.

The evidence suggests that few senior officers actually wanted to sabotage negotiations for good simply because they knew that this would not help them win the war. If they had wanted to do so it would have been easy enough to sabotage the elections of April 1994. What they did intend was to use violence in such a manner as to secure a political settlement on the terms most favourable to white South Africa. As we have seen, even according to this standard, they seriously miscalculated the political effect of Third Force violence in a period of transition and under-estimated the political skill of the ANC leaders, especially after July 1991. Although every week was crucial in the transition period, and crises occurred too often to enumerate, the truly decisive period was probably that from March to September 1992, during which constitutional negotiations broke down and the Boipatong and Bisho massacres threatened a major unravelling of the political fabric. President de Klerk secured a resumption of progress only by aligning himself with those in his party and in the country who were prepared to deal with the ANC on something like the terms it was offering, which would inevitably mean an ANC-dominated government coming to power in the foreseeable future. Thereafter the principal threat to a constitutional transition came from the possibility of an assassination, which required no more than a lone operator, or the activities of a larger group outside the security forces, like the AWB at the Battle of Bop.

Substantial numbers of white extremists who wanted to stop negotiations at all costs were to be found less in the ranks of the Army and the Police than on the civilian extreme right, outside the security forces, in the form of the AWB and similar groups. After the murder of Chris Hani in April 1993 it appeared that such saboteurs were within an ace of succeeding. What was to stop a right-wing maverick from shooting Joe Slovo, or Nelson Mandela? Few senior SADF officers had anything but contempt for the bluster of the AWB or its leader, the loutish Eugene Terreblanche. The problem was that if they expelled the most aggressive covert operatives from the armed forces, the latter were most likely to make common cause with the AWB and others, thus making a descent into civil war more rather than less likely. It was a case of wanting them inside, where they were at least under observation, rather than outside, where all manner: of harm was possible. Once the government had made it clear that it wanted to exert control over the Third Force, which it did after September 1992, it became clear that it had the means to do so, although it was a gradual process. The ANC helped De Klerk to rein in the Third Force by having the wisdom to offer the National Party constitutional terms which were broadly acceptable to the SADF generals, as Afrikaner nationalists, and thus to tempt them into peace, as well as by its political handling of the generals themselves. Even so, the last eighteen months of white South Africa were fraught with danger. Many participants believe that the risk of civil war, particularly after Hani's murder and during the battle of Bophuthatswana in March 1994, was at times very great.

Today, the SADF (now renamed the South African National Defence Force, or SANDF) and the Police (now renamed South African Police Service, or SAPS) continue to serve the state as before. Neither institution can be suspected of harbouring people who have plans to overturn the new order in South Africa. Of the two, the SANDF has the easier task since, despite the central role played by the Chief of Staff (Intelligence) in covert operations from 1978 to 1994, it has emerged from inquiries and from the Truth and Reconciliation Commission less tainted than the Police service. This may be attributed in part to the skill with which the SADF was able to disguise its waging of covert warfare and in part to the political skill with which senior officers played their cards, in effect negotiating with the ANC a soft line on prosecution and various other marks of consideration in return for their 
support for the new government. Since South Africa is not at war and faces no foreseeable military threat from outside its borders, the armed forces can assume a peacetime role in relative comfort.

A far more difficult task faces the Police, tainted by the outrages which they perpetrated before 1994. The Police actually had a less prominent role in the conception and execution of low-intensity warfare than did the SADF, and yet the Police have generally received the greater share of the blame. In retrospect, it may be said that police commanders, quite apart from the other mistakes they made and the great crimes they committed, made a bad job of negotiating their political relations with the ANC as the latter came closer to power. A direct consequence of this is the public opprobrium now being heaped upon the Police, justly, by the hearings of the Truth and Reconciliation Commission and the trial of Eugene de Kock. To add to its woes, the police force now faces the task of policing a highly volatile society containing a dangerous degree of lawlessness, compounded by the ready availability of weapons which were so freely distributed by various armed organisations, including notably Military Intelligence and the Police, before 1994. The police force has shown problems in reorienting itself to these major tasks. Morale is said to be low, and the Police authorities admit to the existence of disturbingly widespread corruption. This is one of the legacies of the dirty war.

Many of the people who actually constituted the Third Force have now left the services. Many senior officers who had responsibility for covert units have retired. Some now work for private security companies or elsewhere in the private sector. Of the middle-ranking officers, Eugene de Kock is serving a 212-year prison sentence. Others have become farmers, administrators or businessmen. Some have established businesses in Mozambique. A few ex-Special Forces personnel have even bought farms in Angola. At least one former Military Intelligence brothel is still functioning in Johannesburg, managed by ex-covert operators, apparently as a purely criminal enterprise. As Eugene de Kock told his judges, with only slight exaggeration, a person with a curriculum vitae like his can choose between becoming a drug smuggler or a mercenary. ${ }^{120}$ Others combine legitimate enterprises with illegal ones both locally and internationally. It appears that some have established interests in the new weapons and narcotics trades and, given the strategic importance of these trades and the huge sums of money which can be generated by narcotics-smuggling, this is of great significance. Here, Mozambique plays a key role, since the country has effectively become a free-trade area for businessmen and smugglers of every description. As it produces little for export and has only a small domestic market, it is essentially an entrepôt for onward trade. Particularly influential are those former South African covert operatives who are acquainted with Mozambican politicians and officials and who are able to use Mozambique as a centre for offshore transactions involving South Africa itself. Some former members of the $\mathrm{CCB}$ are reported to have established a new organisation known as the Binnekring, which combines drug-trafficking and gun-smuggling for profit with activities designed to bolster opposition to the ANC.

While criminal activities of this type are probably carried out largely for profit alone, the fact that some former securocrats remain preoccupied with the long-term future of the Afrikaner volk may provide a continuing link between the more strategic thinkers and former covert operatives now turned professional criminals. The possibility remains that criminal networks which cross South Africa's borders, run by ex-security operatives, could in future provide the sinews of new political movements which derive income partly from criminal activities. If this appears far-fetched, it is worth recalling that, since the end of the

120 Phillip van Niekerk, 'De Vraag is Hoe Lang De Kock Zal Vastzitten', De Volkskrant [Amsterdam], 1 November 1996. 
Cold War, the smuggling of drugs and weapons especially has become connected with new forms of political mobilisation, associated with the use of violence, in many parts of the world.

Occasional incidents cause some observers to wonder whether remnants of the Third Force do not continue to exist as an identifiable series of networks having at least a modicum of political purpose. The fact that still other former covert operatives have found employment in the new, post-apartheid intelligence services, the South African Secret Service and the National Intelligence Agency, further complicates the already complex relationships between former colleagues whose careers have now taken different paths.

Some of the toughest elite troops of the former SADF, including several managers of the CCB death-squad, work for the security company Executive Outcomes Ltd, which has negotiated major contracts for security work with governments in Angola, Sierra Leone and elsewhere. Executive Outcomes is far more than a group of mercenaries. A legitimate company, it employs intelligence analysts and an array of technical staff and, by 1995, it had generated over 30 subsidiary companies throughout sub-Saharan Africa specialising in activities including air transport, video production and mining. It is said to have contracts in Africa, the Indian Ocean and the Middle East.

Other companies which began life in the service of the counter-insurgency strategy of the South African state also continue in business, such as GMR (Pty) Ltd, a company set up by an Italian businessman in the Seychelles and now run by a former naval officer, Willem 'Ters' Ehlers, former private secretary to President P.W. Botha. In 1996, a United Nations inquiry found that Ehlers had sold arms to Hutu extremists in Zairre via the Seychelles. Ehlers is also reported to have traded with UNITA in Angola. ${ }^{121}$ The same report exposed some of the links between drug-trading and weapons-trading in which former South African security men play an important part and which are having a major influence on events in central Africa. ${ }^{122}$

\section{Legacies: Crime and Politics}

South Africa has become a democracy, but the country is now witness to a level of crime which causes deep concern to its citizens and its government. It is said to have one of the world's highest rates of murder. Half the population pronounce themselves in opinion polls to be 'very worried' about becoming victims of crime in their own communities. ${ }^{123}$ The notion that South Africa has solved its outstanding political problems while being saddled with a problem of crime is not a satisfactory analysis. One of the conclusions we may draw from a survey of the last 30 years of South African history is that politics and crime are inter-connected and are not always amenable to conventional analyses, one in the discipline of political science, the other in that of criminology. Furthermore, the abolition of apartheid has had the effect of strengthening South Africa's attachments to a region where states have become weak and informal economies are burgeoning. There are indications that some leading members of the current ANC government have established discreet relations with several old securocrat networks and seek advice from them in a private capacity.

In short, the story of South Africa's constitutional transition, inspiring though it may be, is only one of a number of chronicles which have the power to explain the salient features

121 Ellis, 'Africa and International Corruption', pp. 170-178.

122 United Nations, 'Third Report of the International Commission of Inquiry (Rwanda)', 28 October 1996. Unpublished document.

123 South African Police Service, Report on the Incidence of Serious Crime During 1995 (Pretoria, National Crime Information Management Centre, April 1996), p. 1. 
of the country's recent history. The struggle against apartheid mobilised literally millions of people, often reacting to highly local grievances and political patterns. ${ }^{124}$ These local struggles gave rise to local narratives of violence which at times became subsumed in the national narrative of negotiation, and at other times became disconnected from it. Thus, although the history of the constitutional transition represents the triumph of reason and moderation over violence and bitterness, some regional struggles continue, most obviously in Natal. The fact that local violence between competing factions is nowadays generally regarded as criminal rather than political in nature should not blind us to the fact that many of the participants are the same as those who were regarded as political actors when apartheid was still in place. ${ }^{125}$

At the local level, particularly in poor black communities, armed militias or gangs today attempt to control territory from which they derive economic benefits. Some reach an understanding with local police officers who are unable to enforce the law fully and who may in any case have developed alliances with various unofficial armed groups over many years. Some such groups develop vertical alliances with national political parties and individual politicians who encouraged violence in various ways over many years, or with businessmen who can import the goods which they most require - guns - and wholesale the goods which they offer for export. Prominent among the latter are marijuana and stolen cars (of which there were 98,000 in 1995). ${ }^{126}$ Some criminal middlemen have good connections in politics and the security services, especially those who are themselves veterans of the covert actions of the past. In July 1997, Deputy President Thabo Mbeki claimed in public that a former police brigadier who retired in 1996 was the head of the country's biggest organised crime syndicate. ${ }^{127}$ During the cross-border struggle between the South African security forces and the ANC, SACP, PAC and SWAPO, armed groups of all types sprang up throughout southern Africa, and many of the security and intelligence forces of the region have been penetrated by criminal groups in a complex network of relationships. Senior politicians and intelligence officers in Mozambique are widely believed to have interests in smuggling concerns including the drug trade. The same is true of Zambia, Angola, Seychelles and elsewhere. Thus South Africa's national politics remain related to struggles in South African society (including some generally classified as criminal in nature) and to wider patterns of political and informal economic activity in the region which have become, if anything, even more complex than before.

Part of the reason for the changing pattern of crime and its relation to politics is the failure of the security forces in the 1980s and early 1990s to reflect sufficiently on the evolution of crime and politics both locally and internationally. So intent was the Police on the struggle with the ANC and the SACP during the end-phase of the war for South Africa that officers failed to halt an influx of sophisticated professional criminals from abroad who, after 1990, were able to take advantage of the normalisation of the country's foreign relations to base themselves in South Africa. These include sophisticated Nigerian drugsmuggling syndicates and other similar groups from as far afield as Russia and China. ${ }^{128}$ These international operators have transformed South Africa in just a few years

124 Ineke van Kessel, " "Beyond Our Wildest Dreams": The United Democratic Front and the Transformation of South Africa' (unpublished PhD thesis, University of Leiden, 1995). This important work is to be published by the University of Virginia Press and the University of Natal Press.

125 André du Toit, Understanding South African Political Violence: a New Problematic? (Geneva, Discussion Paper no. 43, United Nations Research Institute for Social Development, 1993).

126 SAPS, Report on the Incidence of Serious Crime During 1995, pp. 31-32.

127 'Ex-Policemen Crime Bosses, Says Mbeki', The Mercury [Durban], 15 July 1997.

128 Some interesting reflections on this are in Edward V. Badolato, 'International Crime Imperils South Africa's Security', Counterterrorism and Security, Fall/Winter 1995, pp. 25-30. The author is a former Deputy Assistant Secretary of the US Department of Energy. 
from a country in which heroin and cocaine were almost unknown to a leading transit-point and a significant market for these products. As in all countries where a significant narcotics trade exists, this has important implications for society and politics.

The countries of southern Africa are closely linked in an economic system constructed by the British government and the great mining houses in the late nineteenth and early twentieth century, with only Angola, of all the countries in the region, standing largely outside this highly integrated trading system. As the outlying parts of the southern African economic system have grown poorer, not least as a result of the war for South Africa which brought about such destruction, so their formal economies have shrunk to be replaced by informal economies and international trades which are technically illicit, but whose existence is widely known. If South Africa remains at the hub of the region's formal economy, it also stands at the centre of this burgeoning smuggling economy and even plays a role in the smuggling networks of the Great Lakes region of Central Africa. It is not only in Mozambique, Angola and Zambia that senior figures in government and the formal economy sometimes play a key role in the smuggling economy as well, but also in South Africa. It was South African Military Intelligence officers who succeeded in establishing Johannesburg as the hub of the ivory and rhino horn trades from the late 1970s, with the personal approval of General Malan, then head of the SADF and later, Minister of Defence. ${ }^{129}$ According to the head of the Organised Crime Unit of the South African Police Service, leading gold smugglers are often rich businessmen seeking to export capital in contravention of currency laws. ${ }^{130}$ South African mines are estimated to lose some 1.5 billion rands' worth of gold per year to theft, and gold smugglers export this by air or sea to neighbouring countries and thence to Europe. The South African diamond marketing cartel, De Beers, has traditionally had an intimate acquaintance with the gem-smuggling trade due to its concern to purchase stones which are unofficially mined and marketed, as well as the official production of various countries.

South Africa attracts criminals from abroad not only because it constitutes a large market for drugs and fraud, but also because it is an ideal base for operations elsewhere. At the same time its relative prosperity attracts millions of people from countries to the north who are not professional criminals, but are simply desperate to earn a living. Here the economic failure of other parts of southern Africa, which the securocrats did much to create by their policy of destabilisation, shapes South Africa's own underground economy. For example, traders from Zambia and Congo seeking to buy consumer goods in South Africa for resale at home often have no access to a suitable form of cash, since the currencies of Congo and Zambia have no international value. They often acquire small quantities of gems, gold, silver, ivory, rhino horn, local works of art or any other goods which are easily transportable and have an international value. These they take to South Africa as a form of currency rather than as a commodity. In a highly organised trade, cars stolen in South Africa are often exported via Mozambique to points further north as far as Nairobi as a form of easily transportable wealth for settlement of debts contracted particularly in the course of drug transactions. Cars stolen in South Africa have also been traced as far afield as Turkey and New Zealand.

Throughout the 1980s, the South African government ignored some of the key changes taking place in the international system of southern Africa, preferring to see everything through a Cold War prism. In fact, politics and economies throughout southern Africa, and many other parts of the world as well, were becoming less formal and less dominated by

129 Kumleben, Commission of Inquiry into the Alleged Smuggling of and Illegal Trade in Ivory and Rhinoceros Horn; Stephen Ellis, 'Of Elephants and Men: Politics and Nature Conservation in South Africa', Journal of Southern African Studies, 20, 1 (1994), pp. 53-70.

130 'Surge in Gold Smuggling Robs Mines and Economy', Business Day, 9 May 1996. 
states as a result of profound changes in international relations. The international context is now quite different from that of the 1980s, and the transformation has been accentuated by South Africa's emergence from international isolation into a world in rapid mutation. In much of Africa, powerful factions and individuals increasingly make use of informal economies and the informal political alliances which produce 'shadow states', ${ }^{131}$ patterns of politics and trade at variance with the official and formal structures which, in theory, exist to articulate these fundamental human activities. Quite apart from the domestic factors which tend to weaken the state's monopoly of violence and which encourage the development of a criminal economy, South Africa cannot stand apart from the trends taking place elsewhere. Some criminal trades, such as the rapidly-increasing drug trade and the trade in illegal weapons, are international in nature. Large amounts of money are generated by these trades and some of the profits are likely to be recycled in the form of political finance by criminal bosses whose aim is to secure political advantage and protection.

Southern Africa is not the only part of the world where politics and crime have become closely associated and South Africa is not the only state which, in its struggle to mobilise all possible means and all available social forces for its own preservation, has condoned the creation of criminal enterprises by its own intelligence officers. The great majority of South African police officers and politicians are deeply concerned by the incidence of crime and its penetration of the state, and they can at least count themselves fortunate that the process has proceeded less far than in some other countries. The formulation of new power-blocs by professional criminals, secret service officers and senior officials working together has not claimed control of the state itself to the same degree as in Russia, for example. ${ }^{132}$ Nor have South African politicians combined tenure of public office with personal enrichment to anything approaching the same extent as in some other important African countries, such as Nigeria and Congo.

In practice, the most pressing question for South Africa is probably to know whether it is possible for criminal activity to be successfully contained in such a manner as to permit the functioning of a conventional political and economic sector, with all that that implies with regard to the rule of law and the security of individuals. Private security guards and fortified suburbs have no doubt become permanent features of South African life, as they have in many other parts of the world. In some parts of South Africa a form of warlordism may have become endemic for the foreseeable future, again like some other parts of the world. This does not necessarily imply the further erosion of the state or even of the conventional business sector since warlordism does not exist in a separate world from official politics but has become an integral part of the political system through the relations between party bosses and the actual perpetrators of violence. The examples of Mexico, Italy and Colombia, to name but three, may well be of relevance to South Africa in showing how a highly developed system of criminal syndicates with connections to political parties and the security forces can co-exist with high rates of economic growth and conventional business activity.

STEPHEN ELLIS

Afrika-Studiecentrum, P.O. Box 9555, 2300 RB Leiden, The Netherlands

131 On 'shadow states', see William Reno, Corruption and State Politics in Sierra Leone (Cambridge University Press, Cambridge, 1995). For a general view, Stephen Ellis, 'Africa After the Cold War: New Patterns of Government and Politics', Development and Change, 27, 1 (1996), pp. 1-28.

132 J. Michael Waller and Victor J. Yasmann, 'Russia's Great Criminal Revolution: the Role of the Security Services', Journal of Contemporary Criminal Justice, 11, 4 (1995), pp. 277-297. 